\title{
The regime of intense desert dust episodes in the Mediterranean based on contemporary satellite observations and ground measurements
}

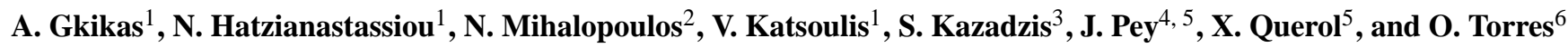 \\ ${ }^{1}$ Laboratory of Meteorology, Department of Physics, University of Ioannina, 45110 Ioannina, Greece \\ ${ }^{2}$ Environmental Chemical Processes Laboratory, Department of Chemistry, University of Crete, P.O. Box 2208, \\ 71003 Heraklion, Crete, Greece \\ ${ }^{3}$ National Observatory of Athens, Institute of Environmental Research and Sustainable Development, Athens, Greece \\ ${ }^{4}$ Department of Epidemiology Lazio Region, via S. Costanza, 53, 00198 Rome, Italy \\ ${ }^{5}$ Institute of Environmental Assessment and Water Research, IDÆA-CSIC C/Jordi Girona, 18-26, 08034 Barcelona, Spain \\ ${ }^{6}$ Joint Center for Earth Systems Technology, University of Maryland, Baltimore County, Baltimore, Maryland, USA
}

Correspondence to: N. Hatzianastassiou (nhatzian@cc.uoi.gr)

Received: 9 March 2013 - Published in Atmos. Chem. Phys. Discuss.: 17 June 2013

Revised: 27 September 2013 - Accepted: 10 October 2013 - Published: 13 December 2013

\begin{abstract}
The regime of intense desert dust (DD) episodes over the broader Mediterranean Basin is studied for the period 2000-2007 at a complete spatial coverage. An objective and dynamic algorithm has been set up which uses daily measurements of various aerosol optical properties taken by different satellite databases, enabling the identification of DD episodes and their classification into strong and extreme ones. The algorithm's performance was tested against surface-based (in situ) particulate matter (PM) and (columnar) sun-photometric AERONET (AErosol RObotic NETwork) measurements from stations distributed across the Mediterranean. The comparisons have shown the reasonable ability of the algorithm to detect the DD episodes taking place within the study region. The largest disagreements with PM data were found in the western Mediterranean in summer, when African dust transport has a great vertical extent that cannot be satisfactorily captured by surface measurements.

According to our results, DD episodes in the Mediterranean Basin are quite frequent (up to 11.4 episodes $\mathrm{yr}^{-1}$ ), while there is a significant spatial and temporal variability in their frequency of occurrence and their intensity. Strong episodes occur more frequently in the western Mediterranean Basin, whilst extreme ones appear more frequently over central Mediterranean Sea areas. Apart from this longitudinal
\end{abstract}

variation, there is a predominant latitudinal variability in both frequency and intensity, with decreasing values from south to north. A significant seasonal variation was also found for the frequency of DD episodes, with both strong and extreme episodes being more frequent during summer in the western Mediterranean Basin, but during spring in its central and eastern parts. In most cases (> 85\%) the Mediterranean dust episodes last a bit longer than a day on average, although their duration can reach six days for strong episodes and four days for extreme episodes. A noticeable year-to-year variability was also found, especially for the frequency of the episodes.

\section{Introduction}

Desert dust aerosols are coarse particles with size distribution showing a dominant coarse mode at $1-5 \mu \mathrm{m}$ and a secondary fine mode around $0.5 \mu \mathrm{m}$ (Tanré et al., 2001) being mainly produced by natural processes and only to a small extent $(<10 \%)$ by agricultural activities (Tegen et al., 2004). They affect climate since they perturb the radiation budget of the Earth-atmosphere system interacting (through scattering and absorption) mainly with solar (shortwave - SW) but also with terrestrial (longwave $-\mathrm{LW}$ ) radiation, respectively producing 
cooling and warming of the Earth-Atmosphere system, either as planetary cooling (e.g. Christopher and Jones, 2007; Xia and Zong, 2009) or warming (e.g. Hatzianastassiou et al., 2004; Papadimas et al., 2012), and depending also on the surface albedo (Osborne et al., 2011; Yang et al., 2009).

Because of their high loadings and large radiative impacts, dust should be considered in climate and weather studies. More specifically, it has been shown in the literature that dust can affect components of the hydrological cycle (Lau et al., 2006; Mallet et al., 2009), cloud properties (e.g. Huang et al., 2006a, b) and precipitation (e.g. Rosenfeld et al., 2001; Hui et al., 2008). Moreover, it has been documented that dust modifies sea surface temperature (e.g. Foltz and McPhaden, 2008) and ocean productivity (e.g. Neff et al., 2008) while having adverse health effects (e.g. Perez et al., 2008; Karanasiou et al., 2012 and references therein). All these impacts of dust along with those on radiation become maximum under conditions of extreme loadings in the atmosphere, namely in the case of dust episodes (or events, Gkikas et al., 2010, 2011; Benas et al., 2011).

The main sources of dust particles are located in the arid and semi-arid regions of the planet, especially in the Northern Hemisphere (Sahara, Arabian Peninsula, Gobi and Taklamakan deserts) and less in the Southern Hemisphere. The deserts of the Sahara and Arabian Peninsula have been identified, based on satellite measurements, as the major dust sources areas over the globe (Prospero et al., 2002; Washington et al., 2003) with the most intense production of dust particles being recorded in Chad, the western Sahara and southern Algeria (Middleton and Goudie, 2001; Barkan et al., 2004).

Aerosol optical depth (AOD) is a realistic measure of columnar aerosol loading and can appropriately describe its spatial and temporal distribution and variability. Since the 1980s and 1990s many researchers (e.g. Jankowiak and Tanré, 1992; Moulin et al., 1997; Remer et al., 2008; Zhang and Reid, 2010) have used satellite observations, taking advantage of their geographically wide view in order to describe globally the spatial distribution of AOD. According to their results, it is evident that significant dust aerosol loads, apart from being observed over the continental source regions, are also transported over oceanic areas, namely towards the Atlantic Ocean from the north African deserts (e.g. Huang et al., 2010) and to Pacific Ocean from Asian deserts (e.g. Eguchi et al., 2009).

The broader Mediterranean Basin is often affected by dust transport because of its proximity to the Sahara to the south and to the Middle East and Arabian Peninsula deserts to the east-southeast (Fig. 1). Dust transport over the Mediterranean, in case of intense low-pressure systems, can travel long enough to reach the northern parts of European continent (Ansmann et al., 2003; Papayannis et al., 2008; Barkan and Alpert, 2010; Klein et al., 2010; Bègue et al., 2012) as well as the Arctic (Barkan and Alpert, 2010). Dust transport towards the Mediterranean is characterized by a seasonal cy- cle (e.g. Moulin et al., 1998; Querol et al., 1998, 2009; Rodríguez et al., 2001; Escudero et al., 2005; Papadimas et al., 2008; Pey et al., 2013) being more intense in its eastern parts in winter and spring, in its central parts during spring and in the western parts in summer. This geographical (longitudinal) shift is driven by the prevailing synoptic conditions (Gkikas et al., 2012). Moreover, it has been documented that the phase of North Atlantic Oscillation (NAO) is a determinant factor for dust abundance in the Mediterranean (Moulin et al., 1997; Antoine and Nobileau, 2006; Pey et al., 2013). Apart from its horizontal movement, dust is also lifted vertically to a significant extent. According to ground-satellite measurements, dust particles have been identified at up to $9-10 \mathrm{~km}$ in the Mediterranean atmosphere (e.g. Gobbi et al., 2000; Mona et al., 2006) although desert dust layers mainly extend between altitudes of 1.5 and $6.5 \mathrm{~km}$ (Papayannis et al., 2005). It has been also found that the most intense Mediterranean dust transport is observed at around $3 \mathrm{~km}$ (Kalivitis et al., 2007). In addition, it has been reported (Hamonou et al., 1999) that several layers of dust from different source regions are often superimposed.

Apart from studies focusing on the spatial and temporal distribution of dust loads in the Mediterranean Basin, dust episodes or events have been also studied, but only on an individual basis (e.g. Dayan et al., 1991; Dulac et al., 1992; Pérez et al., 2006) or over a few years period (e.g. Toledano et al., 2007) and for specific locations (e.g. Kubilay et al., 2003; Meloni et al., 2007). Nevertheless, a complete and comprehensive study dealing with the identification of dust episodes in the whole Mediterranean Basin as well as the determination of their spatio-temporal characteristics is still missing to date. A study of this kind has been conducted by Gkikas et al. (2009) based on a developed algorithm, but dealt with the entire particulate matter, i.e. including other aerosol types and not specifically dust. In the present study, this algorithm is further developed and improved, aiming solely to characterize, identify and study the regime of dust episodes.

The main scope of the present paper is to describe the characteristics of desert dust episodes over the broader Mediterranean Basin. Contrary to previous studies, the dust episodes are homogeneously determined over the entire Mediterranean Basin, thanks to satellite (MODIS, EP-TOMS, OMI) data used, for a relatively long period (7 yr, from March 2000 to February 2007), thus providing a first realistic climatological-like database of the episodes. The identification of episodes is made with an objective and dynamic algorithm, set up here, which uses aerosol optical properties derived from different satellite platforms (Sect. 2). The algorithm is first validated (Sect. 3) through comparison against accurate ground-based (i) particulate matter $\left(\mathrm{PM}_{10}\right)$ concentration measurements and (ii) aerosol optical properties from AErosol RObotic NETwork (AERONET) stations which are located within the study area. Subsequently, the main characteristics of desert dust episodes, namely their frequency, intensity and duration, are examined at the local 


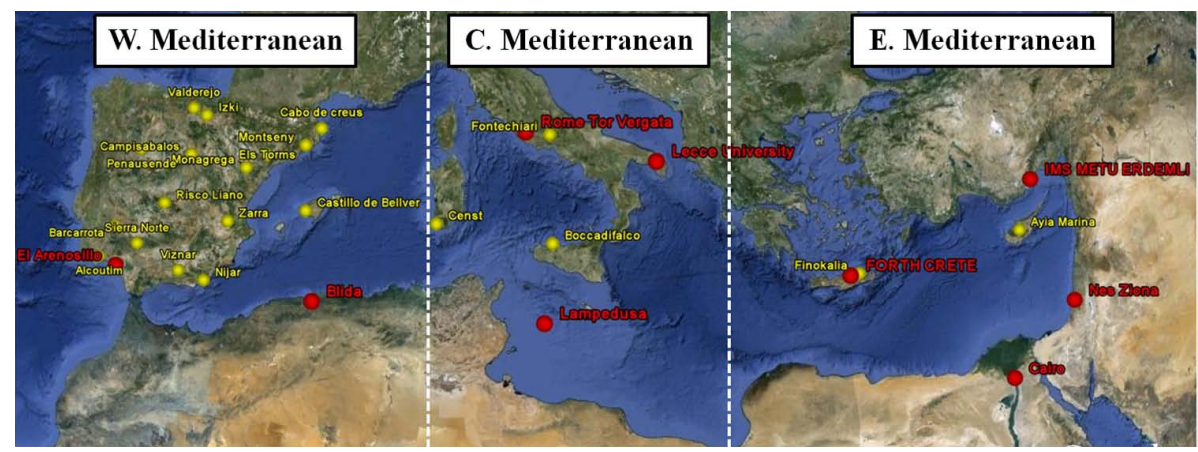

Fig. 1. The study region and stations whose data are used for comparison with the outputs of the present algorithm. Shown are stations providing (i) $\mathrm{PM}_{10}$ measurements (yellow) and (ii) aerosol optical properties (AERONET, red).

scale $\left(1^{\circ} \times 1^{\circ}\right.$ pixel level $)$ by means of geographical distributions (Sect. 4.1), as well as on a mean regional basis (Sect. 4.2). Finally, conclusions are drawn in Sect. 5.

\section{Data and methodology}

\subsection{MODIS Terra}

MODIS Terra level 3 daily gridded atmospheric data product (MOD08_D3) acquired from the MODIS web site ftp: //ladsweb.nascom.nasa.gov/ is used in our analysis. Since February 2000 the MODIS instrument on board the Terra satellite - with daytime equator crossing time at 10:30 and $2330 \mathrm{~km}$ viewing swath - providing almost daily global coverage, has been continuously acquiring measurements at 36 spectral bands between 0.415 and $14.235 \mu \mathrm{m}$ with spatial resolution of 250,500 and $1000 \mathrm{~m}$. MODIS-Terra data were chosen here rather than Aqua ones first because of consistency with our previous studies (Gkikas et al., 2009, 2012) and second in order to cover a longer period (starting from 2000). The retrieval of MODIS aerosol data is performed by special algorithms (see e.g. Kaufman et al., 1997, 2001; Tanré et al., 1997; Levy et al., 2003; Remer et al., 2005), which are different over land and ocean because of their different surface characteristics, and are continuously improved. The MODIS-derived aerosol properties have been extensively validated against AERONET sunphotometer measurements (e.g. Remer et al., 2008; Levy et al., 2010).

Recently, the Collection 005 (C005) MODIS aerosol data were released, derived from a significantly improved retrieval algorithm, being in better agreement with surfacebased AERONET measurements (Levy et al., 2007; Remer et al., 2008). The accuracy of algorithm for MODIS Collection 005 AOD is $\pm 0.05 \pm 0.15 \times$ AOD over land (Levy et al., 2010) and $\pm 0.03 \pm 0.05 \times$ AOD over ocean (Remer et al., 2002). The improvement of MODIS C005 was also seen over the Mediterranean Basin (Papadimas et al., 2009), where the bias of $\mathrm{C} 004$ AOD values (equal to 0.06 with respect to
AERONET) has disappeared in C005 and the correlation coefficient with AERONET increased from 0.66 to 0.76 . Recently, the Collection005 MODIS Terra and Aqua data have also been successfully evaluated against AERONET (Nabat et al., 2013). Here, the following C005 MODIS-Terra data are used: (i) AOD at $\lambda=550 \mathrm{~nm}\left(\mathrm{AOD}_{550 \mathrm{~nm}}\right)$, (ii) Ångström exponent over land $\left(\alpha_{470}-660 \mathrm{~nm}\right)$, (iii) Ångström exponent over ocean $\left(\alpha_{550}-865 \mathrm{~nm}\right)$, (iv) fine-mode fraction (FF) of AOD over land and ocean and (v) Effective radius over ocean $\left(r_{\text {eff }}\right)$. The relevant gridded aerosol data are stored in MODIS level 3 (MOD08_D3) files, each corresponding to daily averages, and reported on a $1^{\circ} \times 1^{\circ}$ latitude-longitude spatial resolution, based on statistics applied to the original $500 \mathrm{~m}$ resolution data. The daily temporal resolution of the data used is appropriate for climatological studies like the present one, though not for case studies. The quality of MOD08_D3 data is satisfactory, since over the course of a day MODIS views the same $1^{\circ}$ square (grid) with a large variety of view angles, which improves the accuracy of calculated flux (Remer and Kaufman, 2006) and aerosol retrievals. The time series of daily MODIS-Terra aerosol data cover the period March 2000-February 2007.

It should be noted that C005 MODIS data do not cover the highly reflecting desert areas of northern Africa (Sahara) due to restrictions in the associated retrieval algorithm. More recently, an improved version of the algorithm, enabling the retrieval of AOD above arid regions, led to the creation of the Deep Blue MODIS database (Collection 051) which covers the Sahara. Nevertheless, the specific database has not been used in the present study mainly for two reasons: (i) because it has not been validated enough yet (e.g. against AERONET) and also (ii) in order to be consistent with our previous study, dealing with the identification of aerosol episodes (Gkikas et al., 2009), in which MODIS C005 data were used.

\subsection{Earth Probe-OMI aerosol index data}

Absorption aerosol index (AI) data were taken from the Earth Probe (based on the Total Ozone Mapping Spectrometer, TOMS) for the period 2000-2004 and OMI-Aura (based 
on Ozone Monitoring Instrument (OMI) measurements since 2005) from NASA's satellite databases (ftp://toms.gsfc.nasa. gov/), together covering the $7 \mathrm{yr}$ period 2000-2007. They both follow up TOMS data, based on TOMS measurements on board Nimbus-7 (1978-1993), Meteor-3 (1991-1994) and Adeos (1996-1997) satellites. All together provide the longest available global aerosol record over land and oceans, starting with TOMS from 11 January 1978 and continuing with the deployment of the EOS-Aura OMI in 15 July 2004 (Torres et al., 2007). This aerosol record is obtained at nearUV spectral wavelengths, where the albedo of land surfaces (including arid and semi-arid areas) is very low, thus making retrievals of AOD possible, especially for absorbing aerosols.

AI with an uncertainty of \pm 0.1 (Torres et al., 2007) is the primary TOMS aerosol product (Herman et al., 1997), provided on a daily basis, and it is a qualitative parameter associated with the presence of UV-absorbing aerosols (e.g. desert dust). The near-UV aerosol retrieval method (full description provided by Torres et al., 1998, 2002) has been applied to observations by TOMS sensor on board the Earth Probe (EP) platform (1996 to 2001). In version 2 of TOMS AI data, the TOMS algorithm, using observations at 331 and $360 \mathrm{~nm}$, has been modified to make it consistent with the inversion procedure used by the Ozone Monitoring Instrument (OMI) sensor (TOMS version 8.5 algorithm), which was launched on board the EOS-Aura satellite (01:38 equator crossing time, ascending mode), and its $2600 \mathrm{~km}$ viewing swath width provides almost daily global coverage. The basic algorithm for OMI uses two wavelengths ( 317.5 and $331.2 \mathrm{~nm}$ under most conditions, and 331.2 and $360 \mathrm{~nm}$ for high ozone and high solar zenith angle conditions). The OMI AI data are calculated from radiance residuals at $360 \mathrm{~nm}$. AI is very nearly proportional to the aerosol absorption optical depth at $360 \mathrm{~nm}$ (Stammes and Noordhoek, 2002). However, the proportionality constant varies with the altitude (of the centre of mass) of the aerosol layer - the lower the altitude, the smaller the constant. Most aerosols have stronger absorption in the UV than in the visible, including mineral dust from deserts and carbonaceous aerosols containing organic and black carbon.

The mean daily AI data used in the present study are a combination of AI values from the Earth Probe and OMIAura satellites, mostly covering different time periods. There is no problem of consistency of AI data from Earth Probe and OMI-Aura since Li et al. (2009) showed that mean annual cycles in the two data sets agree very well both globally and regionally. Since Earth Probe raw data are given at $1^{\circ} \times 1.25^{\circ}$ spatial resolution, they have been re-gridded to $1^{\circ} \times 1^{\circ}$ resolution, on the basis of surface-weighted averages of neighbouring grid cells, in order to match that of the other satellite databases (OMI, MODIS). It should be noted that AI values from OMI-Aura have been adjusted down by one half $n$ value for consistency with the TOMS data record (ftp: //toms.gsfc.nasa.gov/pub/omi/data/aerosol/1README.txt).

\subsection{Surface PM data}

$\mathrm{PM}_{10}$ data from 21 regional background and suburban background sites were used in this study. These monitoring sites (see Fig. 1) are located from the west to east in the Mediterranean as follows: 16 cover the entire Iberian Peninsula and the Balearic Islands; 3 are in Italy, one being close to Rome, another in Sardinia and another one in Sicily; 1 is found in Crete; and 1 is in Cyprus. PM $_{10}$ concentrations were obtained in most cases from gravimetric determinations on filters, whereas in few cases they were determined by realtime instruments (Querol et al., 2009; Pey et al., 2013). All the data used in this study were obtained from public European databases: AirBase (http://acm.eionet.europa.eu/ databases/airbase/), EMEP (www.emep.int/) and EUSAAR (http://www.eusaar.net/).

\subsection{AERONET data}

The aerosol columnar properties used in this work have been obtained from sun-photometric observations performed by the CIMEL sun-sky radiometer. The instruments are part of the AERONET (Holben et al., 1998) global network of stations (http://aeronet.gsfc.nasa.gov). More specifically, data are used from nine AERONET stations found within the limits of the study region (Fig. 1). Note that the general availability of AERONET stations is higher than the stations considered in our analysis. However, we have selected and used only stations that satisfied specific criteria on data availability. More specifically, (i) their period of measurements should overlap with ours (2000-2007), (ii) their location must fall within the area with available satellite data, (iii) they should have data on days with identified desert dust (DD) episodes with our algorithm and (iv) they have data with high accuracy.

The CIMEL data used in this study are level 2.0 and provide information about the columnar AOD and aerosol size distribution. AOD data from the sun photometers have been derived using the direct sun-measuring mode, while the size distribution is calculated based on sky radiance measurements on specific angles along the almucantar and principle solar plane. The channel wavelength configuration is instrument version dependent, but for the above measurements, filters at $440,675,870$ and $1020 \mathrm{~nm}$ wavelengths were always present.

The AERONET technical specifications and the uncertainties of the CIMEL instrument are given in detail in Holben et al. (1998). More specifically, the total uncertainty of the AOD is influenced by various factors (instrumental, calibrationrelated, atmospheric and methodological). The AERONET instrument uncertainty for AOD is $< \pm 0.01$ for wavelengths higher than $440 \mathrm{~nm}$, and $< \pm 0.02$ for UV wavelengths (Eck et al., 1999), or about $10 \%$ for a nominal aerosol optical depth of 0.1 . The uncertainty of the sky radiance data and resulting size distributions are determined based on the calibration 


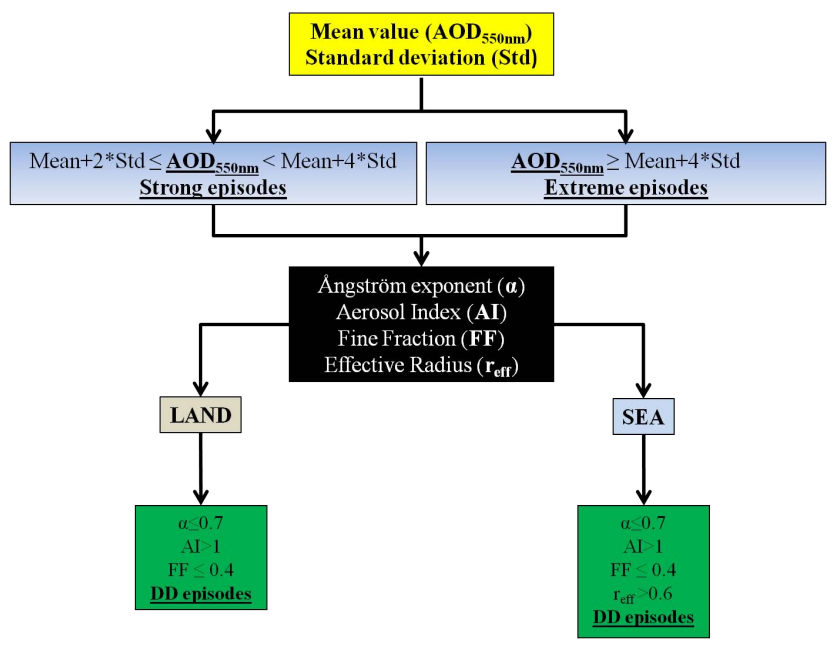

Fig. 2. Flowchart of the developed methodology and algorithm for the identification and characterization of desert dust (DD) aerosol episodes in the Mediterranean Basin.

uncertainty that is assumed $< \pm 5 \%$ for all four wavelength channels (Holben et al., 1998).

\subsection{Methodology}

The procedure used to identify and characterize the intense DD episodes in the Mediterranean Basin is depicted in the flowchart of Fig. 2. It consists of the following steps:

i. First step: mean and associated standard deviation (STDV) AOD $_{550 \mathrm{~nm}}$ values are first computed, for each $1^{\circ} \times 1^{\circ}$ geographical cell, from time series of the pixel's AOD values over the entire study period.

ii. Second step: threshold AOD levels are then defined for each geographical cell, separately for strong (Mean + $2 \mathrm{STDV} \leq \mathrm{AOD}_{550 \mathrm{~nm}}<$ Mean $\left.+4 \mathrm{STDV}\right)$ and extreme $\left(\mathrm{AOD}_{550 \mathrm{~nm}} \geq\right.$ Mean $\left.+4 \mathrm{STDV}\right)$ aerosol episodes. This step, as well as the previous one, aims at the determination/identification of not only DD but in general aerosol episodes based on their loads (by means of AOD), and are described in detail by Gkikas et al. (2009), who applied them for identifying aerosol episodes over the Mediterranean Basin. Also, it must be mentioned that as the thresholds have been defined, the aerosol episodes in the present study are characterized by especially high intensities, which probably can lead to differences with other similar works where episodes of lower intensities are considered.

iii. Third step: this is the key step and consists in the discrimination and characterization of Mediterranean DD episodes among all aerosol episodes identified in the previous step. To this aim, the following properties other than AOD aerosol optical are used: (a) Ångström exponent $(\alpha)$, (b) aerosol index (AI), (c) fine fraction $(\mathrm{FF})$ and $(\mathrm{d})$ effective radius ( $r_{\text {eff }}$, only over sea). The aerosol characterization algorithm is slightly different over land and sea since daily values of $\alpha$, FF and $r_{\text {eff }}$ are derived by MODIS algorithms separately over land and sea. It should be noted that the algorithm is operational only when all of the above satellite data are available. When not, then the algorithm does not produce results, which is often the case in northern Africa's bright surfaces.

A key issue is the selection of appropriate thresholds (cut-off levels) for each one of the algorithm aerosol optical properties. These thresholds have been defined in the present study based on self-performed sensitivity tests, taking into account literature results on aerosol characterization, which are summarized - for $\alpha$, FF, AI and $r_{\text {eff }}$ - in the following few paragraphs. It should be noted that either one of those parameters or a combination of them has been used in the literature for the identification of dust episodes.

\subsection{1 Ångström exponent $(\alpha)$}

Information on the Ångström exponent is useful for separating aerosol particles between fine-mode and coarse-mode ones. The thresholds for $\alpha$ values are different among various studies and regions. Thus, for example, the value of 1 was used for classifying aerosols into fine $(\alpha>1)$ and coarse $(\alpha<1)$ ones (Eck et al., 1999; Holben et al., 2001). Takemura et al. (2002) found that $\alpha$ values are less than 0.4 for Saharan dust (coarse) particles over the subtropical Atlantic. Dubovik et al. (2002), using AERONET data, computed $\alpha<0.9$ in the case of mineral dust particles.

More specifically, as far as the Mediterranean Basin is concerned, Fotiadi et al. (2006) reported that desert aerosols over Crete (eastern Mediterranean Basin) are characterized by $\alpha_{440-870}$ values smaller than $<0.5$, whilst $\alpha$ values smaller than 0.6 were reported by Bryant et al. (2006) for dust particles at Finokalia station (again in Crete) during summer. Pace et al. (2006) reported that at Lampedusa (central Mediterranean), air masses arriving from the Sahara resulted in $\alpha$ values equal to 0.42 . Moreover, during Saharan dust outbreaks, Tafuro et al. (2006) computed a mean $\alpha_{440-870}$ value equal to $0.2 \pm 0.1$ for five different AERONET sites in central Mediterranean, whereas Toledano et al. (2009) reported that dusty conditions were characterized by $\alpha<0.4$ during the SAMUM2006 campaign in Ouarzazate (Morocco).

\subsubsection{Mean effective radius $\left(r_{\text {eff }}\right)$ and fine fraction $(F F)$}

The mean effective radius and fine-mode fraction (of aerosol optical depth or volume size distribution) are also used in the literature as another criterion for discriminating between fine and coarse aerosols. Tanré et al. (2001) used the threshold value $r_{\text {eff }}=0.6$ to discriminate accumulation-mode aerosols from the coarse mode ones and found that at three different 
locations affected by desert dust aerosols, $r_{\text {eff }}$ values were equal to $2.19 \pm 0.12$ (Banizoumbou), $2.15 \pm 0.10$ (Sal Island) and 3.01 \pm 0.24 (Sede Boker). A similar discrimination of dust aerosols was also made by Jones and Christopher (2007) over ocean areas based on a synergistic use of satellite observations and GOCART (Goddard Chemistry Transport Model) model, concluding that mean values of FF and $r_{\text {eff }}$ for desert dust particles were equal to $0.45 \pm 0.05$ and 0.68 , respectively.

\subsubsection{Aerosol index (AI)}

A useful and widely used parameter in aerosol studies is the aerosol index (AI), which is a good and probably the only currently available indicator of aerosol absorptivity. Therefore, it is essential for distinguishing between the two most common types of coarse aerosols, namely dust and sea salt, and determining dust source areas over the globe (Middleton and Goudie, 2001; Prospero et al., 2002; Barkan et al., 2004; Washington et al., 2003). Theoretically (Herman et al., 1997; Torres et al., 1998) negative values of AI indicate the presence of non-absorbing aerosols (e.g. sulfate or sea salt particles), whereas positive AI values (mostly >1) indicate absorbing aerosols (dust or smoke).

\subsubsection{Combination of $\alpha, r_{\text {eff }}$, FF and AI}

Apart from independently using thresholds for each one aerosol parameter to distinguish between different aerosol types, a combination of more than one can lead to more satisfactory results. To this aim, several scientists have used combined data of aerosol optical properties such as AOD, $\alpha$ and FF. Barnaba and Gobbi (2004) used 1 yr level 2 MODIS-Terra data to study the intra-annual variability of specific aerosol types (maritime, continental, dust) over the Mediterranean Basin. To this end, they applied a specific "aerosol mask" to identify desert dust aerosols (FF $<0.7$ and $\mathrm{AOD}_{550 \mathrm{~nm}}>0.3$ ). Kalivitis et al. (2007) identified the presence of desert dust particles over Crete by combining $\mathrm{PM}_{10}$, satellite (TOMS) and AERONET data, and reported that they occur whenever $\mathrm{AOD}_{870 \mathrm{~nm}}>0.2$ and $\alpha_{440-870}<0.6$. Toledano et al. (2007) also detected dust based on routine $6 \mathrm{yr}$ (2000-2005) aerosol measurements at El Arenosillo station (Huelva, Spain) by setting thresholds for $\mathrm{AOD}_{440 \mathrm{~nm}}(>0.25)$ and $\alpha_{440-870}(<0.8)$.

\subsubsection{Present algorithm}

The available information from the literature has been taken into account in our algorithm, and appropriate thresholds have been defined for each one of the four aerosol parameters ( $\alpha, \mathrm{AI}, \mathrm{FF}$, and $r_{\text {eff }}$ ) used to identify Mediterranean DD aerosol episodes. These thresholds are outlined in Fig. 2.

According to our algorithm, desert dust episodes are identified when $\alpha \leq 0.7, \mathrm{AI}>1, \mathrm{FF} \leq 0.4$ and $r_{\text {eff }}>0.6 \mu \mathrm{m}$. It should be noted that $r_{\text {eff }}$ is used in the algorithm only above sea and not land areas because MODIS $r_{\text {eff }}$ values are available only there. Given the availability of slightly different values in the literature, questions may arise concerning the selection of the specific thresholds. To address the sensitivity of the algorithm to individual size parameters ( $\alpha$, FF and $r_{\text {eff }}$ ), several sensitivity tests have been performed changing the associated thresholds. The results show that modifications up to $5 \%$ are found except for FF, for which, only for strong DD episodes over sea, changes can be larger.

\section{Evaluation of the algorithm}

The developed satellite-based algorithm for the determination of DD episodes in the Mediterranean Basin has been evaluated through comparison of its outputs, i.e. the identified strong and extreme DD episodes, with surface data for aerosol physical and optical properties, which are commonly considered as more reliable. In a first step, the algorithm's outputs are compared against surface measurements of $\mathrm{PM}_{10}$ for 21 stations located across the Mediterranean Basin (Fig. 1, yellow). For each station, we have selected/used the satellite measurements for the pixels where stations are found, for cases (days) identified as strong or extreme DD episodes with the algorithm, yielding a number of 333 DD episodes in total. Of course, because of the different nature of surface PM and satellite measurements, difficulties arise when attempting comparisons between them. However, some useful results can be obtained under specific conditions, as we explain below, which support the satellite products. In a second step, a similar analysis was performed, but comparing MODIS-Terra aerosol properties against data from 9 AERONET stations across the Mediterranean Basin (Fig. 1, red) for 58 DD episodes.

\subsection{Particulate matter (PM) measurements}

Figure 3i displays the computed correlation coefficients $(R)$ between surface $\mathrm{PM}_{10}$ concentrations $\left(\mu \mathrm{g} \mathrm{cm}^{-3}\right)$ and satellite AODs (unitless) at $550 \mathrm{~nm}$, under desert dust episodes conditions, for 21 Mediterranean stations. The size of circles, increasing with $R$, indicates how well these two measurements are correlated, while colours are indicative of data availability (red/blue for more/less than 10 episodes). The results show that in most locations, $R$ values are lower than 0.4 (poorest correlation, not statistically significant, in Monagrega, NE Spain), while in six stations $R$ values are larger than 0.5 . The best correlation, statistically significant at $95 \%$ confidence level, is found at the Sicily $(R=0.90)$, Crete ( $R=0.75)$ and Cyprus $(R=0.89)$ stations, opposite to the Iberian Peninsula, where $R$ values are consistently lower. The scatterplot comparisons between ground PM and satellite AOD measurements for the selected 333 DD episodes, obtained separately on a seasonal basis, are depicted in Fig. 3ii-v. The overall comparison is relatively satisfactory 

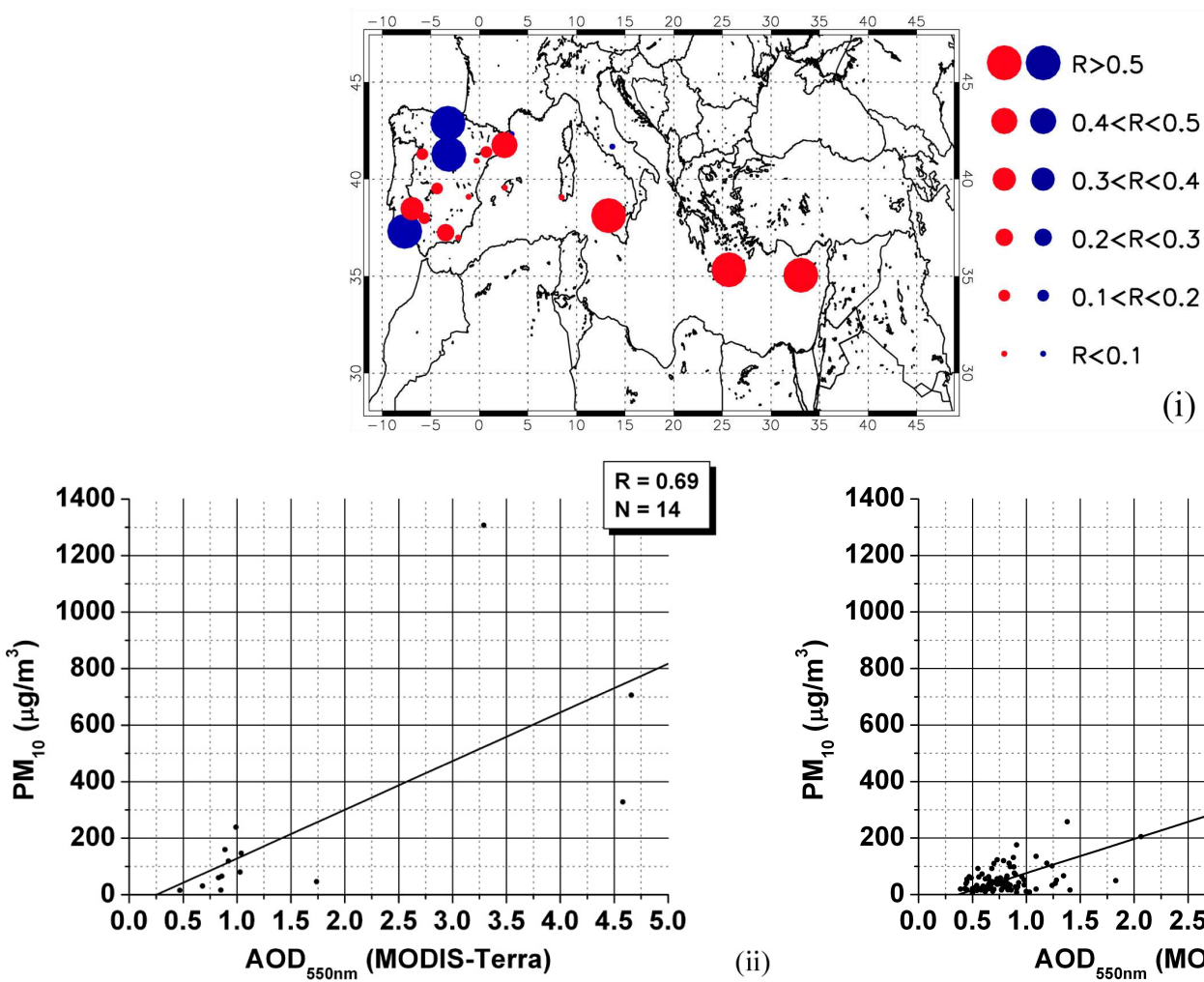

(ii)

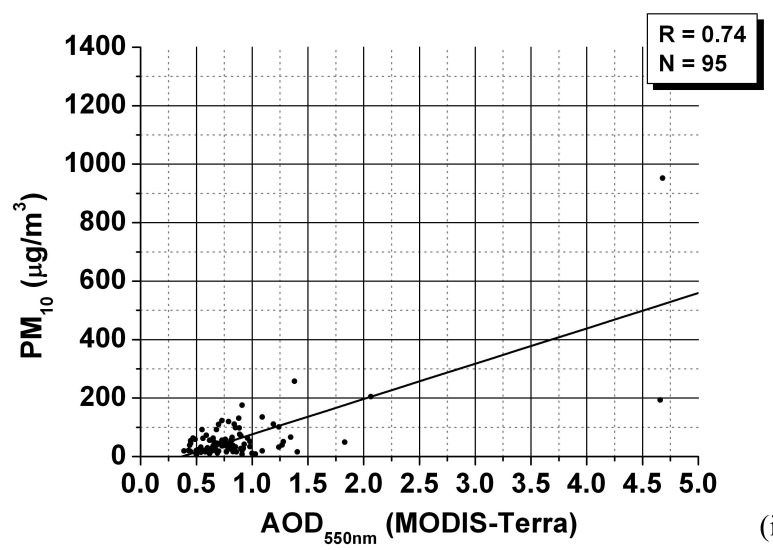

(iii)
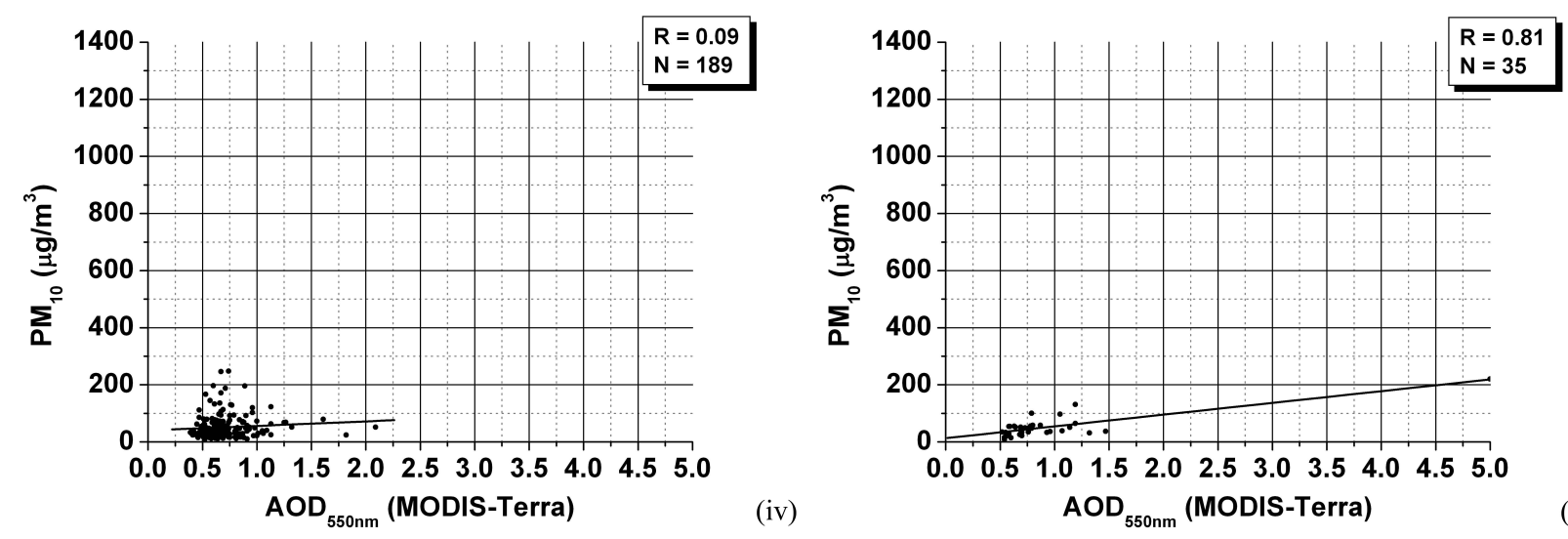

Fig. 3. (i) Computed correlation coefficients between surface $\mathrm{PM}_{10}$ concentrations and AODs, during desert dust episodes and for various stations in the Mediterranean Basin. Red and blue circles represent stations where the selected DD episodes are greater than/equal to and less than 10, respectively. Similar scatterplots, for all stations, between surface $\mathrm{PM}_{10}$ concentrations and AODs during desert episodes are also given for (ii) winter, (iii) spring, (iv) summer and (v) autumn.

taking into account the different nature of compared data, i.e. surface PM measurements against columnar satellite AOD products. The computed overall $R$ value for the 333 DD Mediterranean episodes is equal to 0.64 (statistically significant at $95 \%$ confidence level), while it seems that PM values are biased low with respect to AOD ones. Nevertheless, more information is obtained on a seasonal basis. More specifically, the correlation in winter and spring is good, with $R$ values equal to 0.69 in winter (14 DD episodes) and 0.74 in spring (95 DD episodes), while the correlation is even better in autumn ( $R=0.81,35 \mathrm{DD}$ episodes). It must be mentioned that these three correlation coefficients are statistically significant at $95 \%$ confidence level. Therefore, it appears that if we exclude summer, the correlation between surface PM and satellite AOD products is very good, with $R>0.7$. However, the overall $R$ value drops below 0.7 (0.64) because the major percentage of examined DD episodes (189 out of 333) occurs in summer, when the computed correlation coefficient is very poor $(R=0.09)$ and not statistically significant. The smallest summer $R$ values in Fig. 3iv are essentially in line with the 
low $R$ values over the Iberian Peninsula stations in Fig. 3i, since dust transport in the western parts of the Mediterranean Basin is mainly observed in summer (e.g. Moulin et al., 1998; Antoine and Nobileau, 2006; Toledano et al., 2007; Papadimas et al., 2008; Querol et al., 2009; Pey et al., 2013).

Despite the relatively good performance of our algorithm, in terms of comparison with surface PM products, differences are found, especially in summer. The amplified differences in summertime can be explained by the differences in vertical extension between the two types of products given that dust transport in this season mainly occurs in the free troposphere. Such dust events can be detected by satellite observations but not by surface in situ measurements, like for PM. The vertical extension of dust loads in the Mediterranean Basin has been the subject of several studies (e.g. Hamonou et al., 1999; Berthier et al., 2006; Mona et al., 2006; Di Iorio et al., 2009; Papayannis et al., 2009; Sicard et al., 2011) at different locations in the Mediterranean Basin, mainly based on lidar observations. All these lidar-based studies have documented that transported desert dust particles are more widely vertically extended in summer months, which is meaningful due to stronger convection. Under such conditions, particulate matter can be lifted from the surface, thus restricting the ability of ground PM measurements to record DD episodes and leading to poor correlation between PM and satellite measurements, with the former being biased low. In addition, Kalivitis et al. (2007), using trajectory analyses, found that both free-tropospheric and boundary layer transport of dust (dust observed only at 3000 and $1000 \mathrm{~m}$, respectively) in the eastern Mediterranean become maximum in summer, which also prevents surface PM measurements from recording DD episodes. Finally, CALIOP data for the period 2007-2011 (V. Amiridis, personal communication, 2013) show that dust scale height, i.e. the height above ground where $63 \%$ of the columnar dust load is contained, has values up to $3 \mathrm{~km}$ in summer, being clearly higher (by 1-2 km) than in other seasons. On the other hand, however, it should be also noted that satellite AOD values can be overestimated due to the presence of clouds (cloud contamination) especially under total cloud cover larger than $80 \%$ (Zhang et al., 2005; Remer et al., 2008). In order to investigate this we have re-computed the correlation coefficient between ground (PM) and satellite (MODIS) AOD values excluding points corresponding to cloud fraction larger than $80 \%$ (results not shown here). As a result the $R$ value drastically increased from 0.64 to 0.82 (statistically significant). Finally, a third factor which can affect the quality of our results is that sometimes (e.g. in Fontechiarri, Rome) the common pairs of ground-satellite measurements is small and the computed correlation coefficients for those stations (Fig. 3i) is not necessarily representative.

\subsection{AERONET measurements}

By their nature, AERONET data share more common characteristics with MODIS satellite ones than PM measurements since they are both columnar AOD products based on remote sensing from ground and space, respectively. A total number of 58 identified DD episodes have been examined in this case. Given that for the examined AERONET stations the available AOD values are mostly reported at $440 \mathrm{~nm}$ in order to match the MODIS wavelength $(550 \mathrm{~nm})$, we derived AERONET AODs at $550 \mathrm{~nm}$ from original values at $440 \mathrm{~nm}$ and the Angström exponent between the wavelengths 440 and $870 \mathrm{~nm}$. The overall scatterplot comparison is shown in Fig. 4 i, revealing a relatively good agreement $(R=0.65$, statistically significant at $95 \%$ confidence level) between our algorithm and AERONET in the case of dust events. Again, MODIS AODs seem to be overestimated (bias $=0.22$ ), especially for low AODs (smaller than 0.4), while the situation is improved for stronger dust episodes (higher than 0.8).

The validity of the algorithm products was checked in another way by examining the aerosol volume size distributions for the 58 DD episodes. To this aim, and also to highlight the difference made under episode conditions, data of volume size distribution were taken from AERONET and subsequently have been averaged both for all observations (blue) and for only the $58 \mathrm{DD}$ episodes (red) for the 9 Mediterranean stations. The results (Fig. 4ii) make that evident that under DD episodes in the Mediterranean, the aerosol coarse mode is strongly increased - by a factor of $\sim 10$, with a volume distribution peak at $2.24 \mu \mathrm{m}$ - due to the predominance of coarse dust particles. The Mediterranean DD episodes' aerosol volume size distribution (red curve) is still bimodal, with a further decreased fine mode compared to the overall distribution (all observations, blue curve).

\section{Desert dust episodes regime}

\subsection{Geographical patterns}

\subsubsection{Frequency of occurrence}

The averaged (2000-2007) geographical distributions of the frequency of occurrence (episodes $\mathrm{yr}^{-1}$ ) of strong and extreme DD episodes in the Mediterranean Basin are presented in Fig. 5i and ii, respectively. It is evident that there is a dominant south-north decreasing gradient, along with a smaller west-east gradient. Thus, strong DD episodes occur more frequently in the western parts of the Mediterranean (11.4 episodes $\mathrm{yr}^{-1}$ over the northwestern coasts of Africa), dropping to less than 3.5 episodes $\mathrm{yr}^{-1}$ in the eastern part of the basin. On the other hand, extreme DD episodes are mostly observed in the central Mediterranean (up to 3.9 episodes $\mathrm{yr}^{-1}$ in Gulf of Sidra), whereas their maximum frequencies are systematically observed over sea surfaces, opposite to strong episodes mostly occurring over land. Of 

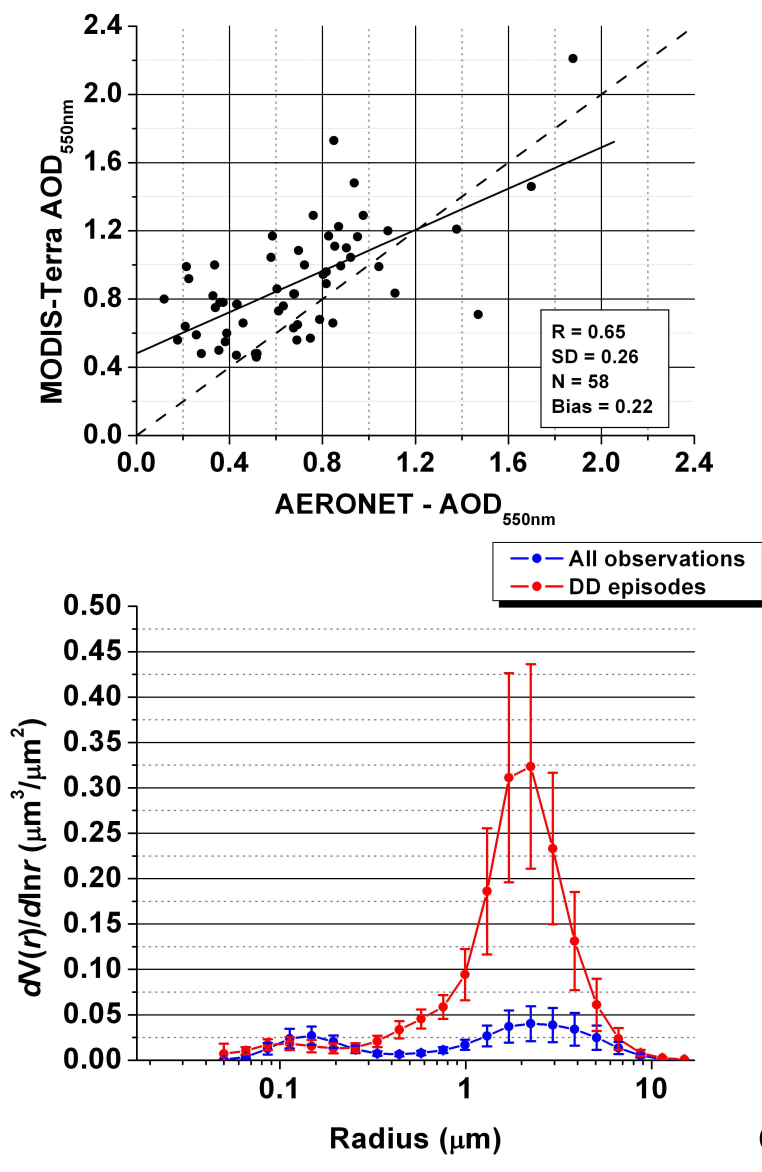

Fig. 4. (i) Scatterplot between AERONET and MODIS-Terra AODs at $550 \mathrm{~nm}$ under desert dust episode conditions and (ii) average volume size distribution for all observations (blue curve) and desert dust episode conditions (red curve). The error bars represent the standard deviation values.

course it should be kept in mind that the land areas of north Africa, where episodes occur presumably very often, are not considered in our analysis. The south-north gradient has been also observed from a ground-based monitoring perspective (Querol et al., 2009; Pey et al., 2013). However, Pey et al. (2013) reported a slight east-west decreasing gradient and even higher frequencies of dust events compared to ours, which can be both attributed to the use of surface PM measurements in that study and also to the different definitions of dust events with our study.

The predominant south-north increasing gradient of DD episodes frequency is reasonable since it is known (e.g. Mona et al., 2006; Israelevich et al., 2012) that Mediterranean regions in the vicinity primarily of the Sahara and secondarily of Middle East deserts are frequently affected by the transport of desert particles. Our frequencies when compared to those of the literature for specific locations throughout the study region may be found somewhat smaller, but this can

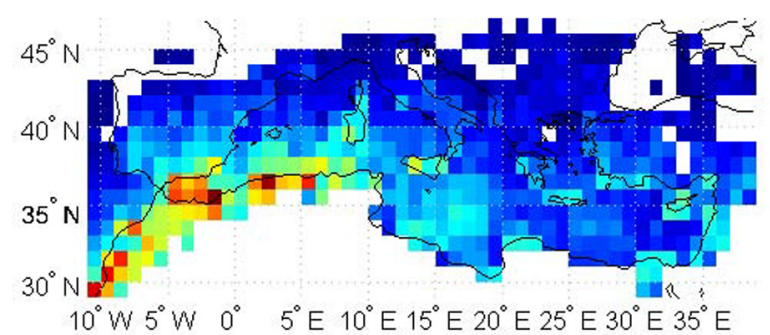

(i)

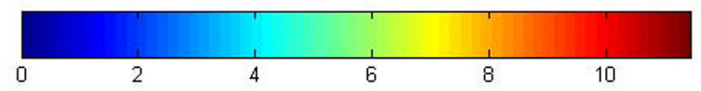

(ii)

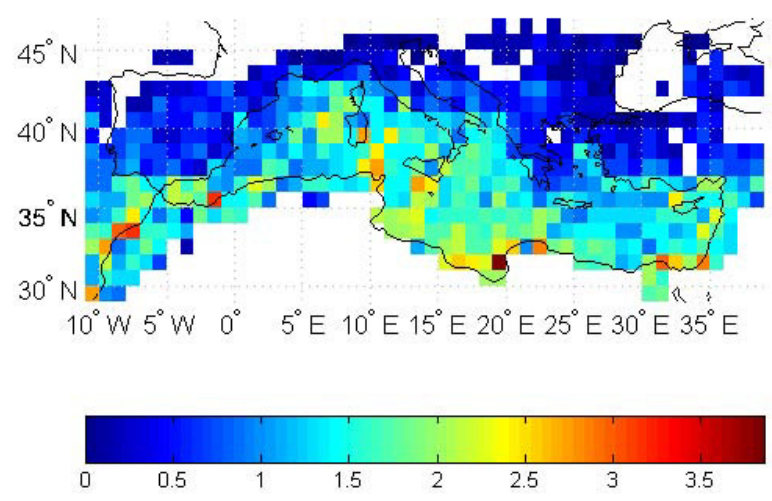

Fig. 5. Geographical distributions of the frequency of occurrence (episodes $\mathrm{yr}^{-1}$ ) of (i) strong and (ii) extreme DD episodes over the broader Mediterranean Basin for the period 2000-2007. White pixels correspond to cases with missing data.

be explained by the different nature of data used and to the different applied methodologies. According to our results, continental central European areas exhibit low frequencies $\left(<1\right.$ episode $\left.\mathrm{yr}^{-1}\right)$ indicating that desert dust can impact remote areas, which can be even more distant based on the literature (Ansmann et al., 2003; Borbely-Kiss et al., 2004; Klein et al., 2010).

The seasonal (DJF for winter, MAM for spring, JJA for summer and SON for autumn) maps of DD episodes frequency indicate that there is a longitudinal shift of the activity of both strong and extreme DD events (Figs. 6i and ii, respectively). Thus, during autumn, strong DD episodes occur more frequently over the central Mediterranean Sea (but with relatively low frequencies of 1.9 episodes season ${ }^{-1}$ ), while in spring and winter they occur more often in the eastern Mediterranean with higher frequencies (up to 3.9 episodes season ${ }^{-1}$ ). On the other hand, the highest frequencies of strong DD episodes are observed in summer (8.1 episodes season ${ }^{-1}$ ) and take place in the western parts of the basin. The longitudinal shift of DD episodes throughout the year is associated with the prevailing cyclonic (cold winter and spring Sharav cyclones) and anticyclonic (Azores 

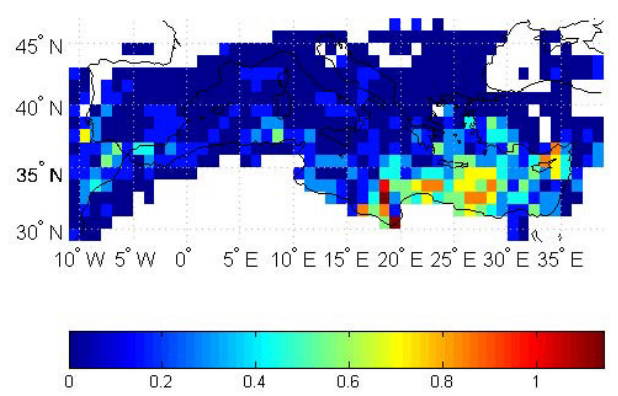

(ii-a)
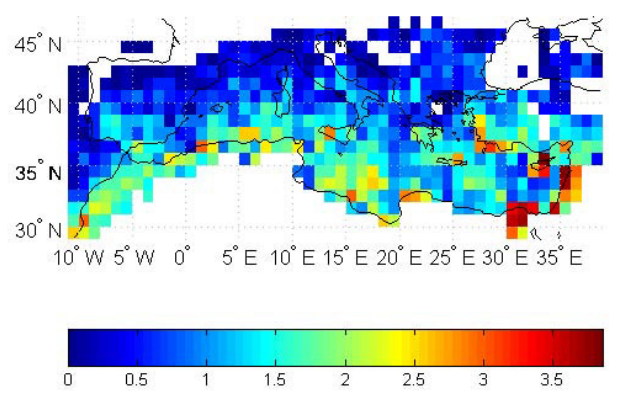

(iii-a)
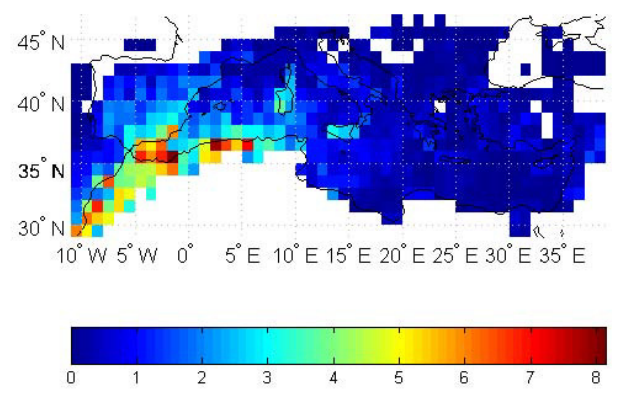

(iv-a)
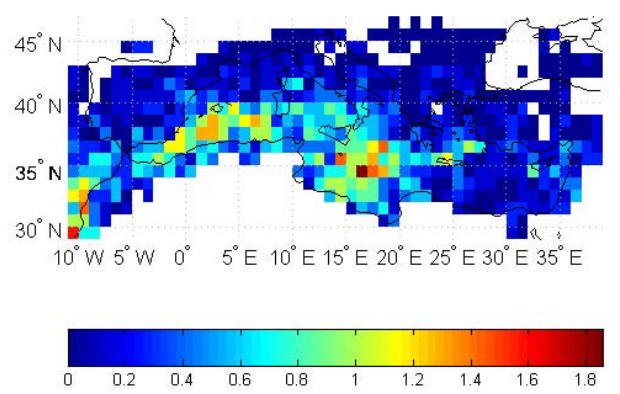
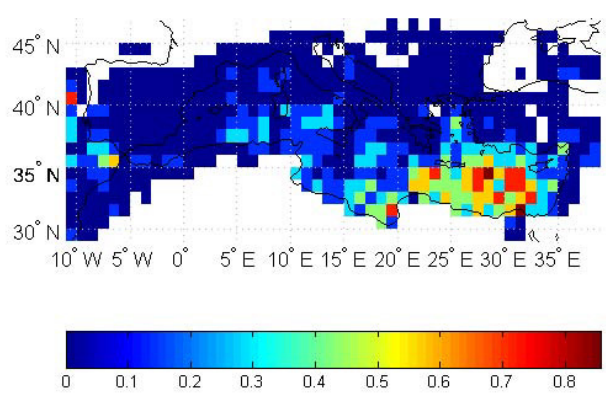

(ii-b)
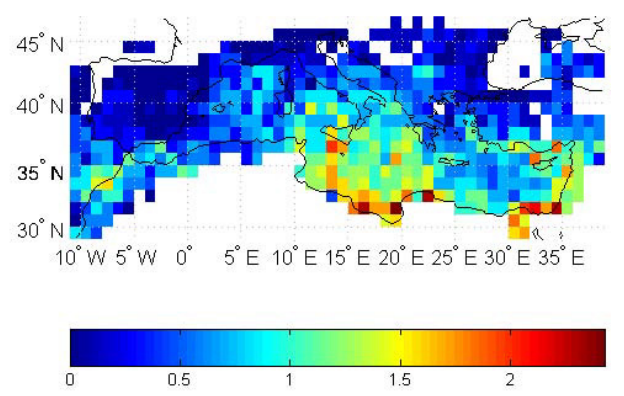

(iii-b)
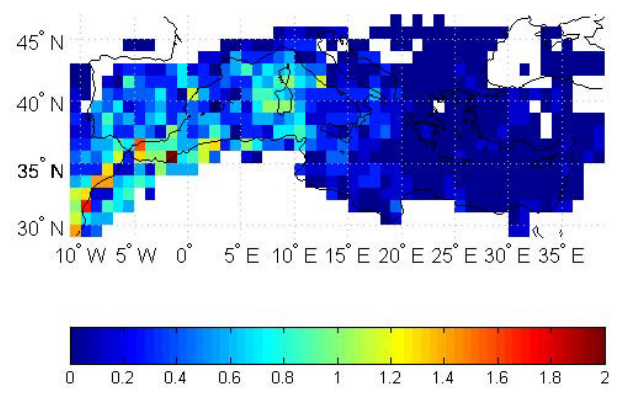

(iv-b)
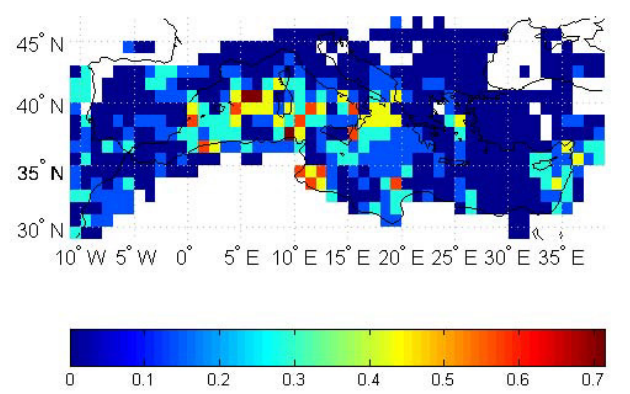

Fig. 6. Seasonal geographical distributions of the frequency of occurrence (episodes season ${ }^{-1}$ ) of (a) strong and (b) extreme DD episodes taking place in (i) winter, (ii) spring, (iii) summer and (iv) autumn over the Mediterranean Basin for the period 2000-2007. 
anticyclone) systems transporting dust from the Sahara into the basin (Alpert et al., 1990; Moulin et al., 1998; Barkan et al., 2005). As for extreme DD episodes, during winter, maximum frequencies are found over the eastern Mediterranean $\left(0.9\right.$ episodes season $\left.{ }^{-1}\right)$, during spring over the central Mediterranean Sea (2.4 episodes season ${ }^{-1}$ ) and during summer and autumn over the western parts of the basin ( 2 and 0.7 episodes season ${ }^{-1}$, respectively).

\subsubsection{Intensity}

The intensity of strong and extreme DD episodes (Fig. 7i and ii) in terms of $\mathrm{AOD}_{550 \mathrm{~nm}}$ exhibits more different spatial patterns than their frequency. The highest intensities appear off the African coasts of the central (strong DD episodes) and eastern (extreme DD episodes) Mediterranean Basin. It should be noted that spatial patterns of the intensity of DD episodes closely resemble those of overall aerosol episodes as they were shown by Gkikas et al. (2009). This proves that DDs dominate aerosol episodes in the Mediterranean Basin in terms of their intensity. Strong and extreme DD episodes are characterized by AOD values of up to 1.5 and 4.1, respectively, being in general more intense over sea than land surfaces. It should be kept in mind, however, that this is because northern African regions (where AOD values are even greater than over adjacent coasts) are mostly not covered by our results because of the limited availability of C005 MODIS data and also the applied $50 \%$ data availability criterion (see Gkikas et al., 2009). On a seasonal basis, the geographical distributions of DD intensity (not shown here) do not reveal significant differences from the mean annual ones, opposite to what happens with frequency. As expected, our results demonstrate a pronounced decreasing south-north gradient for both strong and extreme episodes, highlighting the determining role of African dust for AOD levels over the Mediterranean Basin, especially in the case of dust outbreaks. The lack of similarity between the spatio-temporal patterns of intensity and frequency of Mediterranean DD episodes can be explained by the different nature of these two parameters. It is also different because of the different factors that determine these two quantities and the spatial extent of their action. For example, the patterns of frequency of DD episodes can be generally regulated by the distribution patterns of pressure systems, while their intensity is mostly related to individual strong pressure systems.

\subsubsection{Duration}

The computed mean duration (in days) of strong and extreme DD episodes in the Mediterranean Basin is presented in Fig. 8i and ii, respectively. The strong DD episodes last slightly longer in the western part (up to 1.4 days) than in other parts of the basin, with maximum duration over Morocco. The extreme episodes are characterized by a reverse gradient, with longer episodes in the eastern Mediterranean (i)
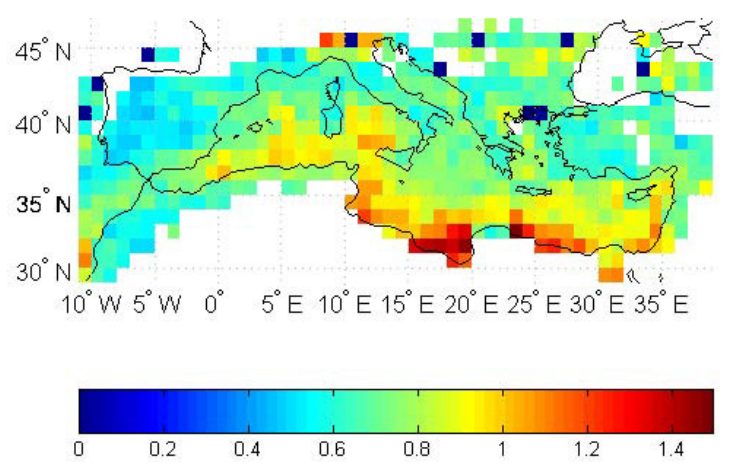

(ii)

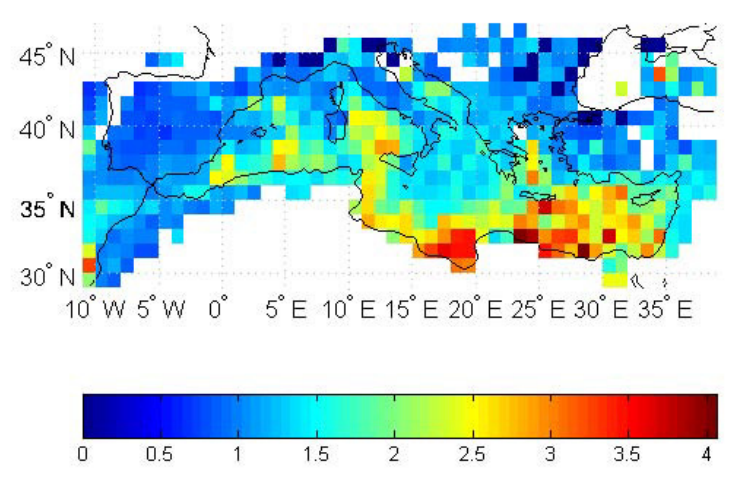

Fig. 7. Geographical distributions of the intensity, in terms of $\mathrm{AOD}_{550 \mathrm{~nm}}$, of (i) strong and (ii) extreme DD episodes over the broader Mediterranean Basin for the period 2000-2007.

Basin (up to 1.5 days in eastern Mediterranean) and maximum duration in the southern Levantine Sea. Long extreme DD episodes are also found in the eastern parts of the Atlantic Ocean.

Averaged duration results over 2000-2007 presented in Fig. 8 mask specific, considerably longer, individual DD episodes (more for strong than extreme episodes). Thus, during the study period, three strong dust episodes (in Morocco, July 2003) lasted up to six days, while a single extreme DD episode lasted four days and took place between 2 and 5 April 2000 in the sea region between Cyprus and Turkey (Kubilay et al., 2003). More than $85 \%$ of all identified DD episodes in the broader Mediterranean Basin last about one day, yielding a regional mean duration equal to 1.12 days for strong DD episodes over continental, and 1.08 days for extreme DD episodes over maritime areas. The computed duration of DD episodes in this study may seem somewhat short, but duration here is given on the timescale of 1 day, 
(i)
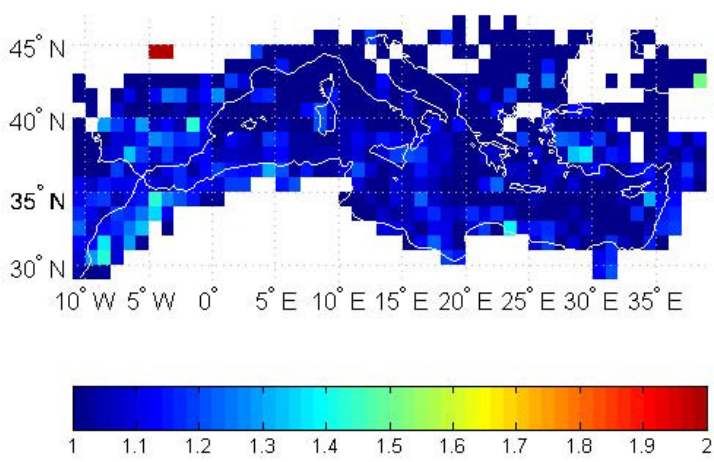

(ii)
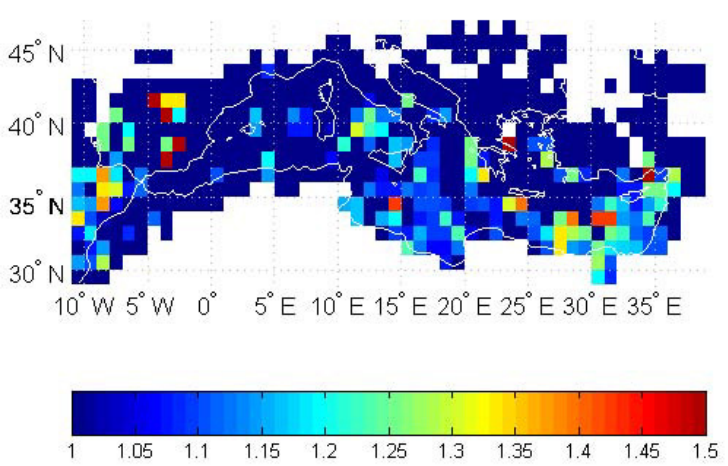

Fig. 8. Geographical distributions of the duration (in days) of (i) strong and (ii) extreme DD episodes over the broader Mediterranean Basin for the period 2000-2007.

which implies that half a day corresponds to $12 \mathrm{~h}$ (and a decimal point to about $2.5 \mathrm{~h}$, which is meaningful).

\subsection{Temporal variability}

Given the allowed satisfactory spatial coverage by the satellite data used in the present work it is possible to study not only the geographical but also the temporal variation of Mediterranean DD aerosol episodes, for both the entire region and specific sub-regions. Thus, the intra-annual (seasonal) and inter-annual variations of strong and extreme DD episodes have been studied for the broader Mediterranean Basin, as well as also separately for its western, central and eastern parts, and for land and sea surfaces.

\subsubsection{Seasonal variability}

The seasonal frequencies of occurrence (relative percent terms) of strong and extreme DD episodes are given in Table 1. Apart from the whole Mediterranean Basin, results are separately computed over continental (land) and maritime (sea) areas of the basin as well as for its western, central and eastern sections.

\section{Continental areas}

Over continental areas of the Mediterranean, strong DD episodes occur more frequently in summer $(51.4 \%)$. This is actually observed in the western $(67.3 \%)$ and central $(51.5 \%)$ sections of the basin, but not in the eastern one, where maximum frequency occurs in spring $(71 \%)$. Strong Mediterranean DD episodes take place secondarily in spring, with percentages of 25.5-40.4\%, except for the eastern basin (summer secondary maximum). The seasonal regime of DD episodes is more different for extreme than strong ones. Thus, extreme episodes occur more frequently in spring, both in central $(60.4 \%)$ and eastern $(87.7 \%)$ parts of the basin, as well as in the entire basin $(61.1 \%)$, while in the western basin they are more frequently observed in summer $(54.2 \%)$.

\section{Maritime areas}

Over maritime areas of the Mediterranean Basin the seasonality of DD episodes shows a slightly more different behaviour than over continental regions. Thus, for the entire basin, the maximum frequencies of occurrence are recorded in spring, both for strong (43.4\%) and extreme (57.2\%) episodes, opposite to more frequent continental episodes in summer. This specific seasonality, i.e. spring maxima both for strong and extreme episodes, is observed for the central (46.8\% strong DD, $63.8 \%$ extreme DD) and eastern (61.9\% strong DD, $67.4 \%$ extreme DD) parts of the Mediterranean Sea, while only in its western parts do DD episodes occur more frequently in summer (49.5 and $42.2 \%$ for strong and extreme, respectively). Not only the geographical, but also the temporal variation of Mediterranean DD aerosol episodes is possible to be studied, for the entire region and specific sub-regions, thanks to the allowed satisfactory spatial coverage by the satellite data used in the present work. In addition, another factor that probably explains the low frequencies in winter could be observational difficulties for satellites caused by extended cloud coverage.

\section{Other studies}

Our findings cannot be easily compared to other observational ones since they are the first with a complete spatial coverage for the studied period, namely subsequent to 2000 , opposite to existing studies performed either for specific locations (Toledano et al., 2007; Meloni et al., 2007) or previous periods (Moulin et al., 1998). The seasonal spatial characteristics of dust transport in the broader Mediterranean Basin has been studied by a few more researchers using satellite data but over short periods (e.g. Barnaba and Gobbi, 2004) or different periods to ours (Antoine and Nobileau, 2006) or indirectly, i.e. through total AOD and 
Table 1. Seasonal frequency of occurrence (in percent values of annual occurrences) of strong and extreme DD aerosol episodes over land and sea surfaces of the entire Mediterranean basin, and over western, central and eastern Mediterranean, during the period 2000-2007. The total annual number of DD episodes is also given in each case. Maximum frequencies are indicated with bold numbers and the second largest frequencies with italic numbers.

\begin{tabular}{|c|c|c|c|c|c|c|c|c|}
\hline & \multicolumn{8}{|c|}{ LAND } \\
\hline & \multicolumn{2}{|c|}{ Mediterranean } & \multicolumn{2}{|c|}{ W. Mediterranean } & \multicolumn{2}{|c|}{ C. Mediterranean } & \multicolumn{2}{|c|}{ E. Mediterranean } \\
\hline & strong & extreme & strong & extreme & strong & extreme & strong & extreme \\
\hline Winter & $1.6 \%$ & $1.5 \%$ & $1 \%$ & $1.2 \%$ & $0.4 \%$ & $1.5 \%$ & $3.3 \%$ & $2 \%$ \\
\hline Spring & $40.4 \%$ & $61.1 \%$ & $25.5 \%$ & $37.4 \%$ & $38.4 \%$ & $60.4 \%$ & $71 \%$ & $87.7 \%$ \\
\hline Summer & $51.4 \%$ & $30.9 \%$ & $67.3 \%$ & $54.2 \%$ & $51.5 \%$ & $31.4 \%$ & $19 \%$ & $4.6 \%$ \\
\hline Autumn & $6.6 \%$ & $6.5 \%$ & $6.2 \%$ & $7.2 \%$ & $9.7 \%$ & $6.7 \%$ & $6.7 \%$ & $5.7 \%$ \\
\hline \multirow[t]{4}{*}{ Total number } & 5702 & 1491 & 3446 & 685 & 534 & 194 & 1722 & 612 \\
\hline & \multicolumn{8}{|c|}{ SEA } \\
\hline & \multicolumn{2}{|c|}{ Mediterranean } & \multicolumn{2}{|c|}{ W. Mediterranean } & \multicolumn{2}{|c|}{ C. Mediterranean } & \multicolumn{2}{|c|}{ E. Mediterranean } \\
\hline & strong & extreme & strong & extreme & strong & extreme & strong & extreme \\
\hline Winter & $9.1 \%$ & $13.3 \%$ & $4.1 \%$ & $6.3 \%$ & $6.2 \%$ & $8.4 \%$ & $20.6 \%$ & $26.3 \%$ \\
\hline Spring & $43.4 \%$ & $57.2 \%$ & $27 \%$ & $37.3 \%$ & $46.8 \%$ & $63.8 \%$ & $61.9 \%$ & $67.4 \%$ \\
\hline Summer & $29 \%$ & $18.4 \%$ & $49.5 \%$ & $42.2 \%$ & $24.7 \%$ & $14.5 \%$ & $6 \%$ & $0.9 \%$ \\
\hline Autumn & $18.5 \%$ & $11.1 \%$ & $19.4 \%$ & $14.2 \%$ & $22.3 \%$ & $13.3 \%$ & $11.5 \%$ & $5.4 \%$ \\
\hline Total number & 4886 & 2966 & 1794 & 867 & 1852 & 1184 & 1240 & 915 \\
\hline
\end{tabular}

size parameters distributions (e.g. Papadimas et al., 2008). Moreover, this was also attempted based on model simulations (e.g. Basart et al., 2012). In summary, the findings of the aforementioned studies are in agreement with our results as to the previously discussed seasonal variability of dust in the Mediterranean.

\subsubsection{Inter-annual variability}

Previous studies (e.g. Papadimas et al., 2008; Hatzianastassiou et al., 2009; Yoon et al., 2011) have shown that there is a significant year-to-year variability of aerosol loadings in the Mediterranean Basin. Moreover, Gkikas et al. (2009) have shown that such a significant inter-annual variability, in terms of frequency and intensity, also exists for maximum aerosol loadings, i.e. aerosol episodes.

More specifically, we attempted here to examine the inter-annual variability of dust episodes (outbreaks) in the Mediterranean Basin. The aim is to quantify this variability in terms of frequency of occurrence and intensity of DD episodes, which are both very important in many aspects. Computations are performed separately over Mediterranean land and sea areas and for strong and extreme DD episodes. The frequency is normalized to be expressed in number of events per unit area $\left(1^{\circ} \times 1^{\circ}\right.$ latitude-longitude or about $100 \mathrm{~km} \times 100 \mathrm{~km}$ ), while the intensity is expressed in terms of $\mathrm{AOD}_{550 \mathrm{~nm}}$.

\section{Frequency of occurrence of DD episodes}

The Mediterranean DD episodes depict a seasonal cycle with maximum frequencies, as already noted in Sect. 4.2.1, during the dry period of the year (spring-summer) and minimum appearances in the wet period (autumn-winter). The spring maxima are usually observed in April, whereas summer ones in July. The relative strength of maximum spring/summer frequencies is different when examined for different subregions, e.g. western/central/eastern basins, or for strong and extreme DD episodes, separately. Thus, subregional results (not shown here) indicate that summer maxima are primary in the western Mediterranean Basin, whereas in the central and especially in the eastern Mediterranean, the spring maxima become primary, in agreement with the findings of Table 1. Also, the two maxima are about equivalent for strong DD episodes, while the spring maxima clearly become primary in the case of extreme episodes. Differences in frequencies are also encountered between strong and extreme episodes, as well as between land and sea Mediterranean areas. More specifically, frequencies of strong episodes reach values up to about 1.2 episodes pixel ${ }^{-1}$, whereas those of extreme episodes hardly exceed 1.0 episode pixel $^{-1}$, and are higher over sea than land areas. There is a significant yearto-year variability of frequencies of DD episodes, especially over land, with an absolute maximum of 1.2 episodes pixel ${ }^{-1}$ for strong episodes in July of 2003 (similar high frequencies were also observed in July 2002 and April 2000). A more distinct absolute maximum frequency of extreme DD 
episodes (again, 1.2 episodes pixel ${ }^{-1}$ ) is found over land in April 2000, but high frequencies are also observed in April 2003. Therefore, according to our results, years 2000 (April) and 2003 (July) seem to have been marked by the most frequent DD episodes over Mediterranean land areas. More specifically, according to the reproduced AOD maps with the Giovanni tool (http://disc.sci.gsfc.nasa.gov/ giovanni/overview/index.html), for each day of April 2000 and July 2003, a significant portion of the eastern Mediterranean Basin in April 2000, as well as the western Mediterranean in July 2003, is characterized by AOD values higher than 0.5 .

The applied linear regression fit to time series of Fig. 9 (blue lines) indicates that strong and extreme DD episodes occurred in the Mediterranean Basin over the period of 20002007 with decreasing frequencies (statistically significant at $95 \%$ confidence level) over land surfaces. However, no statistically significant trends are found over Mediterranean Sea areas. The tendencies of frequencies of strong and extreme DD episodes have been also checked using anomalies instead of absolute frequency values, and the results, i.e. decreasing frequencies (see Supplement Fig. S4), remain the same. This is also valid when using annual frequencies (again not shown here). According to Fig. 9, it appears that the decreasing tendency of occurrence of DD episodes in the Mediterranean is mainly caused by low spring and summer frequencies in years 2005-2007 combined with high frequencies in years 2000 and 2003.

\section{Intensity of DD episodes}

As to the inter-annual variation of the intensity of DD aerosol episodes (red lines in Fig. 9), our results do not indicate a clear seasonal cycle, both for the strong and extreme episodes. In general, the intensity of Mediterranean DD aerosol episodes is higher over maritime than continental areas. The maximum regional mean intensity of strong DD episodes is equal to 0.96 over land (in December 2000) and 1.23 over sea (in November 2004). The corresponding values for extreme DD episodes are equal to 1.5 (May 2001) and 4.86 (January 2004). The changing intensity of Mediterranean DD aerosol episodes is possibly related to modifications of the position and strength of pressure systems, as well as the instability of the atmosphere, since there is a strong connection between atmospheric circulation and associated desert dust concentrations. Of course, this deserves further and more thorough investigation, which is beyond the scope or the present work.

\section{Summary and conclusions}

The present study aims to describe, for the first time, to our knowledge, the regime of intense desert dust episodes that takes place over the entire Mediterranean Basin. To this end, an objective and dynamic algorithm has been set up which identified the DD episodes that occurred over the period 2000-2007. As input data, the algorithm uses daily aerosol optical properties provided at $1^{\circ} \times 1^{\circ}$ spatial resolution, derived from MODIS, Earth Probe and OMI satellite measurements, for the following parameters: aerosol index (AI), fine fraction (FF), Ångström exponent $(\alpha)$ and effective radius ( $r_{\text {eff }}$, over sea only). The identified DD episodes were classified into strong and extreme ones, based on their intensity, by means of aerosol optical depth (AOD). The algorithm determined the main characteristics of DD episodes, namely their frequency, intensity and duration, at various spatial (from pixel level to regional mean) and temporal (from daily to $7 \mathrm{yr}$ means) scales.

First, the performance of the algorithm has been tested against quality surface measurements. This was done for 333 pixel-level DD episodes collocated with selected stations found within the study region. An initial evaluation was performed using daily $\mathrm{PM}_{10}$ concentration data from 21 stations across the Mediterranean Basin. The results revealed a very good agreement between ground and satellite measurements for central and eastern Mediterranean stations (correlation coefficient $(R)$ values up to 0.91 ) against lower $R$ values over the western basin. More information was obtained performing the validation on a seasonal basis. More specifically, there was a moderate-to-good agreement in winter ( $R=0.69)$, spring $(R=0.74)$ and autumn $(R=0.81)$, contrary to poor correlation in summer $(R=0.09)$, which can be attributed to the higher vertical extension of dust loadings during this season. This vertically extended dust transport, far above the boundary layer, does not allow for them to be captured by ground stations measuring PM, since their in situ measurements are restricted to the surface air layer. In a second approach, the algorithm's performance has been also evaluated against aerosol optical properties from nine AERONET stations across the Mediterranean Basin. This has been done for 58 DD episodes, and the comparison revealed (i) a relatively good correlation $(R=0.65)$ between MODIS and AERONET AOD values and (ii) a significant increase (by a factor of $\sim 10$ ) of coarse-mode particles (dominated by dust, centred at $2.24 \mu \mathrm{m}$ ) in the case of DD episodes relative to all cases.

The following is the case according to our computed geographical distributions:

- There is a longitudinal gradient in the frequency of occurrence of Mediterranean DD episodes. This gradient is more evident for strong episodes, which occur more frequently (up to 11.4 episodes $\mathrm{yr}^{-1}$ ) in the western Mediterranean Basin, and less evident for the (more sparse) extreme episodes, which occur more frequently in the central basin (up to 3.9 episodes $\mathrm{yr}^{-1}$ ).

- There is also a clear and predominant latitudinal gradient, with frequencies of both strong and extreme DD 

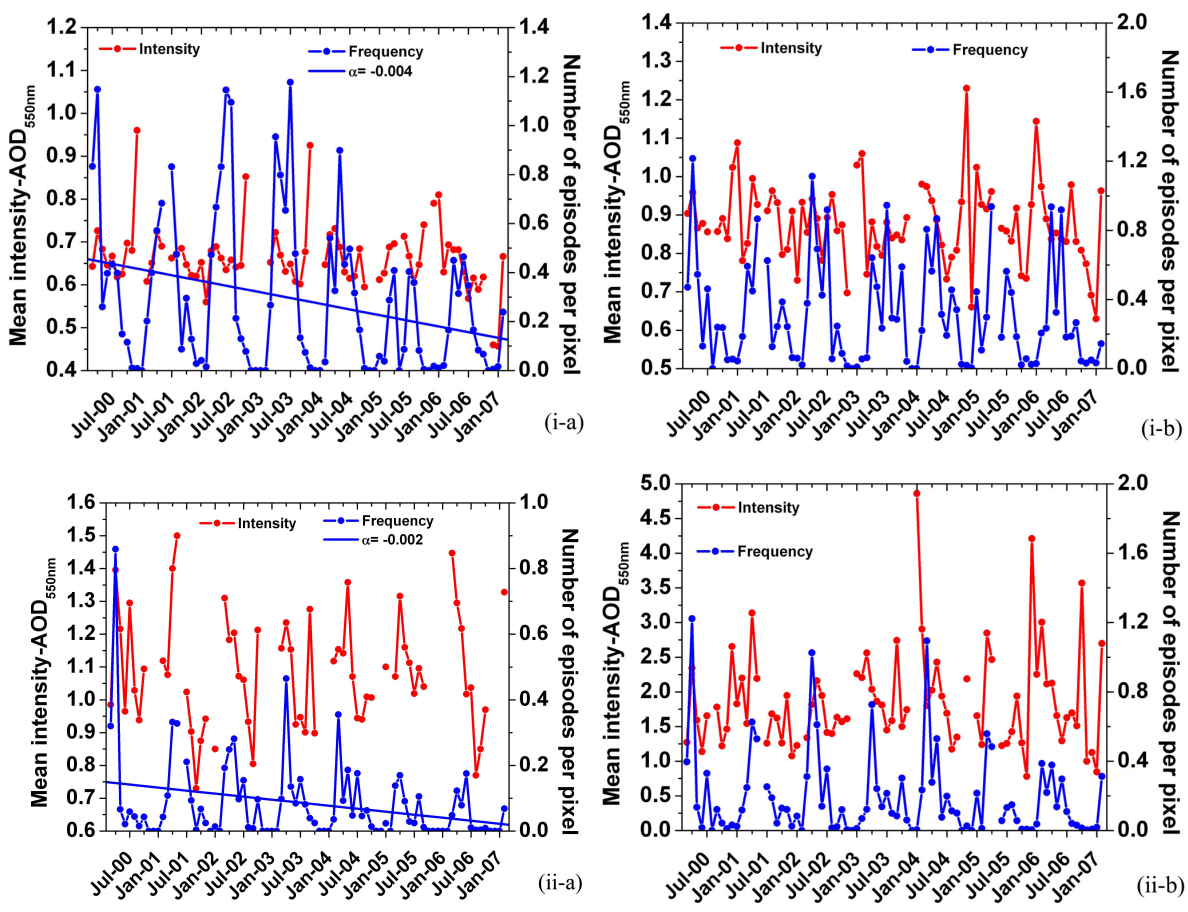

Fig. 9. Inter-annual variation and tendencies of monthly mean frequency (blue curves) and intensity (red curves) of (i) strong and (ii) extreme DD aerosol episodes taking place over (a) land and (b) sea surfaces of the broader Mediterranean Basin for the period 2000-2007.

episodes decreasing from south to north, as the distance from the north African desert areas increases, while a west-east gradient is evident only for the strong ones, likely determined by the climatology of the pressure systems.

- The geographical variability of DD episodes' frequency in the Mediterranean, and specifically that of the longitudinal one, appears to be driven by precipitation patterns and the prevailing pressure systems in the area. This is confirmed by the spatial variability of frequency dust throughout the course of year. Thus, in the eastern Mediterranean Basin, the DD episodes occur more frequently in spring (up to 3.9 episodes $\mathrm{yr}^{-1}$ ) and winter (up to 1 episode $\mathrm{yr}^{-1}$ ), having in both seasons the maximum frequencies over the entire basin. Correspondingly, in central parts of the Mediterranean Basin maximum DD episode frequencies are observed in spring (up to 3 episodes $\mathrm{yr}^{-1}$ ) and in the western parts of the basin in summer (up to 8.1 episodes yr).

- The intensity of strong DD episodes (in terms of $\mathrm{AOD}_{550 \mathrm{~nm}}$ values) in the Mediterranean varies from 0.4 to 1.5 (Gulf of Sidra, Libyan Sea). The intensity of extreme DD episodes is however significantly higher, varying from 0.7 to 4.1 (Libyan Sea). Although there is an apparent south-north gradient in the intensity of DD episodes, similarly to their frequency, there is no similarity between intensity and frequency in terms of their spatio-temporal patterns.

- As for their duration, it is found that the strong DD episodes last up to 1.4 days $(34 \mathrm{~h})$ in the western Mediterranean Basin, while the extreme ones can be more persistent in the eastern parts, lasting up to 1.5 days ( $36 \mathrm{~h})$.

- The comparison of our results (DD episodes) with those corresponding to all episodes given by Gkikas et al. (2009) demonstrates that there is a similarity between them, which shows the significant contribution of DD episodes. According to our computations, the contribution of DD episodes is equal to 32.7 and $40.1 \%$ for strong episodes over land and sea, respectively, while for extreme episodes the corresponding values rise to 49 and $71.5 \%$.

The analysis of intra-annual (seasonal) and inter-annual (year-to-year) variation of Mediterranean DD episodes reveals the following:

- For the entire Mediterranean Basin, on average, there is a different seasonality over land and sea areas (on the basis of regions covered by available satellite data). Thus, strong Mediterranean DD episodes over land occur more frequently in summer $(51.4 \%)$, whilst over sea they are more frequent in spring $(61.1 \%)$. Correspondingly, extreme desert dust episodes are by far 
more frequent in spring over both continental (43.4\%) and maritime $(57.2 \%)$ areas of the Mediterranean Basin.

- When examining the seasonality of DD episodes at a smaller spatial scale - i.e. for different subregions, namely western, central and eastern parts of the basin differences are found. Thus, our results indicate that in the western Mediterranean Basin, DD episodes (both strong and extreme) occur more frequently in summer. Conversely, in the central and eastern parts of the Mediterranean Basin, DD episodes are more common in spring; however, strong episodes over land areas of the central part of the basin occur more frequently in summer.

- In general, there appears to be a quite stable year-toyear seasonality of DD episodes, in line with that described above.

- Our results indicate that DD episodes in the Mediterranean decreased between years 2000 and 2007 over land surfaces.

It is planned to supplement and improve the results of this study in the near future in various aspects. (i) A larger spatial coverage of the study region will be possible using MODIS Deep Blue aerosol data - which are also available over the highly reflecting deserts of the Sahara and Middle East - after these data have been adequately validated. (ii) A larger temporal coverage is also desirable, which will strengthen our findings as to seasonal and inter-annual variability of Mediterranean DD episodes. (iii) The accumulation of enough data derived from satellite-based lidar systems over time will offer a robust evaluation of the outputs of our algorithm through comparisons against vertically resolved CALIOP aerosol information, which directly specifies the existence of various aerosol types with height. (iv) Finally, the study will be repeated in other dust-dominated key world regions, for example the Gobi and Taklimakan deserts.

\section{Supplementary material related to this article is available online at http://www.atmos-chem-phys.net/13/ 12135/2013/acp-13-12135-2013-supplement.pdf.}

Acknowledgements. This research has been co-financed by the European Union (European Social Fund - ESF) and Greek national funds through the operational programme "Education and Lifelong Learning" of the National Strategic Reference Framework (NSRF) - Research Funding Program: ARISTEIA-PANOPLY. Investing in knowledge society through the European Social Fund. The Earth Probe (TOMS) and OMI aerosol climatology is available from the TOMS website (http://toms.gsfc.nasa.gov). The Collection
005 MODIS-Terra data were obtained from NASA's level 1 and Atmosphere Archive and Distribution System (LAADS) website (ftp://ladsweb.nascom.nasa.gov/). We would like to thank the principal investigators maintaining the nine AERONET sites used in the present work. We would like to acknowledge the EMEP programme and the public European databases Airbase and ACTRIS, which supplied $\mathrm{PM}_{10}$ data used in this study. The authors also thank F. Dulac and two anonymous reviewers for their helpful comments that improved the final version of our manuscript.

Edited by: G. Kallos

\section{References}

Alpert, P., Neeman, B. U., and Shay-EL, Y.: Climatological analysis of Mediterranean cyclones using ECMWF data, Tellus, 42, 6577, 1990.

Ansmann, A., Bösenberg, J., Chaikovsky, A., Comerón, A., Eckhardt, S., Eixmann, R., Freudenthaler, V., Ginoux, P., Komguem, L., Linné, H., López Márquez, M. A., Matthias, V., Mattis, I., Mitev, V., Müller, D., Music, S., Nickovic, S., Pelon, J., Sauvage, L., Sobolewsky, P., Srivastava, M. K., Stohl, A., Torres, O., Vaughan, G., Wandinger, U., and Wiegner, M.: Long-range transport of Saharan dust to northern Europe: The 11-16 October 2001 outbreak observed with EARLINET, J. Geophys. Res., 108, 4783, doi:10.1029/2003JD003757, 2003.

Antoine, D. and Nobileau, D.: Recent increase of Saharan dust transport over the Mediterranean Sea, as revealed from ocean color satellite (SeaWiFS) observations, J. Geophys. Res., 111, D12214, doi:10.1029/2005JD006795, 2006.

Barkan, J. and Alpert, P.: Synoptic analysis of a rare event of Saharan dust reaching the Arctic region, Weather, 65, 208-211, doi:10.1002/wea.503, 2010.

Barkan, J., Alpert, P., Kutiel, H., and Kishcha, P.: Synoptics of dust transportation days from Africa toward Italy and central Europe, J. Geophys. Res., 110, D07208, doi:10.1029/2004JD005222, 2005.

Barkan, J., Kutiel, H., and Alpert, P.: Climatology of Dust Sources in North Africa and the Arabian Peninsula, Based on TOMS data, Indoor Built Environ., 13, 407-419, 2004.

Barnaba, F. and Gobbi, G. P.: Aerosol seasonal variability over the Mediterranean region and relative impact of maritime, continental and Saharan dust particles over the basin from MODIS data in the year 2001, Atmos. Chem. Phys., 4, 2367-2391, doi:10.5194/acp-4-2367-2004, 2004.

Basart, S., Pérez, C., Nickovic, S., Cuevas, E., and Baldasano, J. M.: Development and evaluation of the BSCDREAM8b dust regional model over Northern Africa, the Mediterranean and the Middle East, Tellus B, 64, 18539, doi:10.3402/tellusb.v64i0.18539, 2012.

Bègue, N., Tulet, P., Chaboureau, J.-P., Roberts, G., Gomes, L., and Mallet, M.: Long-range transport of Saharan dust over northwestern Europe during EUCAARI 2008 campaign: Evolution of dust optical properties by scavenging, J. Geophys. Res., 117, D17201, doi:10.1029/2012JD017611, 2012.

Benas, N., Hatzianastassiou, N., Matsoukas, C., Fotiadi, A., Mihalopoulos, N., and Vardavas, I.: Aerosol shortwave direct radiative effect and forcing based on MODIS Level 2 data in the 
Eastern Mediterranean (Crete), Atmos. Chem. Phys., 11, 1264712662, doi:10.5194/acp-11-12647-2011, 2011.

Berthier, S., Chazette, P., Couvert, P., Pelon, J., Dulac, F., Thieuleux, F., Moulin, C., and Pain, T.: Desert dust aerosol columnar properties over ocean and continental Africa from Lidar in-Space Technology Experiment (LITE) and Meteosat synergy, J. Geophys. Res., 111, D21202, doi:10.1029/2005JD006999, 2006.

Borbély-Kiss, I., Kiss, Á. Z., Koltay, E., Szabó, G., and Bozó, L.: Saharan dust episodes in Hungarian aerosol: elemental signatures and transport trajectories, Aerosol Sci., 35, 1205-1224, 2004.

Bryant, C., Eleftheriadis, K., Smolik, J., Zdimal, V., Mihalopoulos, N., and Colbeck, I.: Optical properties of aerosols over the Eastern Mediterranean, Atmos. Environ., 40, 6229-6244, 2006.

Christopher, S. A. and Jones, T.: Satellite-based assessment of cloud-free net radiative effect of dust aerosols over the Atlantic Ocean, Geophys. Res. Lett., 34, L02810, doi:10.1029/2006GL027783, 2007.

Dayan, U., Heffter, J., Miller, J., and Gutman, G.: Dust intrusion events into the Mediterranean basin, J. Appl. Meteorol., 30, 1185-1199, 1991.

Di Iorio, T., di Sarra, A., Sferlazzo, D. M., Cacciani, M., Meloni, D., Monteleone, F., Fùa, D., and Fiocco, G.: Seasonal evolution of the tropospheric aerosol vertical profile in the central Mediterranean and role of desert dust, J. Geophys. Res., 114, D02201, doi:10.1029/2008JD010593, 2009.

Dubovik, O., Holber, B., Eck, T. F., Smirnov, A., Kaufman, Y. J., King, M. D., Tanre, D., and Slutsker, I.: Variability of Absorption and Optical Properties of Key Aerosol Types Observed in Worldwide Locations, J. Atmos. Sci., 59, 590-608, 2002.

Dulac, F., Tanré, D., Bergametti, G., Buat-Méenard, P., Desbois, M., and Sutton, D.: Assessment of the African airborne dust mass over the Western Mediterranean sea using Meteosat data, J. Geophys. Res., 97, 2489-2506, 1992.

Eck, T. F., Holben, B. N., Reid, J. S., Dubovik, O., Smirnov, A., O’ Neill, N. T., Slutsker, I., and Kinne, S.: Wavelength dependence of the optical depth of biomass burning, urban, and desert dust aerosols, J. Geophys. Res., 104, 31333-31349, 1999.

Eguchi, K., Uno, I., Yumimoto, K., Takemura, T., Shimizu, A., Sugimoto, N., and Liu, Z.: Trans-pacific dust transport: integrated analysis of NASA/CALIPSO and a global aerosol transport model, Atmos. Chem. Phys., 9, 3137-3145, doi:10.5194/acp-93137-2009, 2009.

Escudero, M., Castillo, S., Querol, X., Avila, A., Alarcón, M., Viana, M. M., Alastuey, A., Cuevas, E., and Rodríguez, S.: Wet and dry African dust episodes over Eastern Spain, J. Geophys. Res., 110, D18S08, doi:10.1029/2004JD004731, 2005.

Foltz, G. R. and McPhaden, M. J.: Impact of Saharan dust on tropical North Atlantic SST, J. Clim., 21, 5048-5060, doi:10.1175/2008JCLI2232.1, 2008.

Fotiadi, A., Hatzianastassiou, N., Drakakis, E., Matsoukas, C., Pavlakis, K. G., Hatzidimitriou, D., Gerasopoulos, E., Mihalopoulos, N., and Vardavas, I.: Aerosol physical and optical properties in the Eastern Mediterranean Basin, Crete, from Aerosol Robotic Network data, Atmos. Chem. Phys., 6, 53995413, doi:10.5194/acp-6-5399-2006, 2006.

Gkikas, A., Hatzianastassiou, N., and Mihalopoulos, N.: Aerosol events in the broader Mediterranean basin based on 7-year
(2000-2007) MODIS C005 data, Ann. Geophys., 27, 35093522, doi:10.5194/angeo-27-3509-2009, 2009.

Gkikas, A., Hatzianastassiou, N., and Mihalopoulos, N.: Direct radiative effect of extreme desert dust episodes in the Mediterranean basin, International Aerosol Conference, Finland, Helsinski, 2F3, 29 August-3 September 2010, 2010.

Gkikas, A., Hatzianastassiou, N., and Mihalopoulos, N.: Direct effect of extreme aerosol episodes on atmospheric solar radiation in the broader Mediterranean basin and potential links with atmospheric dynamics, Geophysical Research Abstracts, 13, EGU2011-12581, EGU General Assembly 2011, 2011.

Gkikas, A., Houssos, E. E., Hatzianastassiou, N., Papadimas, C. D., and Bartzokas, A.: Synoptic conditions favouring the occurrence of aerosol episodes over the broader Mediterranean basin, Q. J. Roy. Meteorol. Soc., 138, 932-949, doi:10.1002/qj.978, 2012.

Gobbi, G. P., Barnaba, F., Giorgi, R., and Santacasa, A.: Altituderesolved properties of a Saharan dust event over the Mediterranean, Atmos. Environ., 34, 5119-5127, 2000.

Hamonou, E., Chazette, P., Balis, D., Dulac, F., Schneider, X., Galani, E., Ancellet, G., and Papayannis, A.: Characterization of the vertical structure of Saharan dust export to the Mediterranean basin, J. Geophys. Res., 104, 22257-22270, 1999.

Hatzianastassiou, N., Katsoulis, B., and Vardavas, I.: Global distribution of aerosol direct radiative forcing in the ultraviolet and visible arising under clear skies, Tellus, 56, 51-71, 2004.

Hatzianastassiou, N., Gkikas, A., Mihalopoulos, N., Torres, O., and Katsoulis, B. D.: Natural versus anthropogenic aerosols in the eastern Mediterranean basin derived from multi-year TOMS and MODIS satellite data, J. Geophys. Res., 114, D24202, doi:10.1029/2009JD011982, 2009.

Herman, J. R., Bhartia, P. K., Torres, O., Hsu, N. C., Seftor, C. J., and Celarier, E.: Global distribution of UV-absorbing aerosols from Nimbus-7/ TOMS data, J. Geophys. Res., 102, 1691116923, 1997.

Holben, B. N., Eck, T. F., Slutsker, I., Tanré, D., Buis, J. P., Setzer, A., Vermote, E., Reagan, J. A., Kaufman, Y. J., Nakajima, T., Lavenu, F., Jankowiak, I., and Smirnov, A.: AERONET - A federated instrument network and data archive for aerosol characterization, Remote Sens. Environ., 66, 1-16, 1998.

Holben, B. N., Tanre, D., Smirnov, A., Eck, T. F., Slutsker, I., Abuhassan, N., Newcomb, W. W., Schafer, J., Chatenet, B., Lavenue, F., Kaufman, Y. J., Vande Castle, J., Setzer, A., Markham, B., Clark, D., Frouin, R., Halthore, R., Karnieli, A., O’Neill, N. T., Pietras, C., Pinker, R. T., Voss, K., and Zibordi, G.: : An emerging ground-based aerosol climatology: Aerosol optical depth from AERONET, J. Geophys. Res., 106, 12067-12097, doi:10.1029/2001JD900014, 2001.

Huang, J., Lin, B., Minnis, P., Wang, T., Wang, X., Hu, Y., Yi, Y., and Ayers, J. K.: Satellite-based assessment of possible dust aerosols semi-direct effect on cloud water path over East Asia, Geophys. Res. Lett., 33, L19802, doi:10.1029/2006GL026561, 2006a.

Huang, J., Minnis, P., Lin, B., Wang, T., Yi, Y., Hu, Y., SunMack, S., and Ayers, K.: Possible influences of Asian dust aerosols on cloud properties and radiative forcing observed from MODIS and CERES, Geophys. Res. Lett., 33, L06824, doi:10.1029/2005GL024724, 2006b.

Huang, J., Zhang, C., and Prospero, J. M.: African dust outbreaks: A satellite perspective of temporal and spatial variability over 
the tropical Atlantic Ocean, J. Geophys. Res., 115, D05202, doi:10.1029/2009JD012516, 2010.

Hui, W. J., Cook, B. I., Ravi, S., Fuentes, J. D., and D'Odorico, P.: Dust-rainfall feedbacks in the West African Sahel, Water Resour. Res., 44, W05202, doi:10.1029/2008WR006885, 2008.

Israelevich, P., Ganor, E., Alpert, P., Kishcha, P., and Stupp, A.: Predominant transport paths of Saharan dust over the Mediterranean Sea to Europe, J. Geophys. Res., 117, D02205, doi:10.1029/2011JD016482, 2012.

Jankowiak, I. and Tanré, D.: Satellite Climatology of Saharan Dust Outbreaks: Method and Preliminary Results, J. Climate, 5, 646-656, doi:10.1175/15200442(1992)005<0646:SCOSDO>2.0.CO;2, 1992.

Jones, T. A and Christopher, S. A.: MODIS derived fine mode fraction characteristics of marine, dust, and anthropogenic aerosols over the ocean, constrained by GOCART, MOPITT, and TOMS, J. Geophys. Res., 112, D22204, doi:10.1029/2007JD008974, 2007

Kalivitis, N., Gerasopoulos, E., Vrekoussis, M., Kouvarakis, G., Kubilay, N., Hatzianastassiou, N., Vardavas, I., and Mihalopoulos, N.: Dust transport over the eastern Mediterranean derived from TOMS, AERONET and surface measurements, J. Geophys. Res., 112, D03202, doi:10.1029/2006JD007510, 2007.

Karanasiou, A., Moreno, N., Moreno, T., Viana, M., de Leeuw, F., Querol, X.: Health effects from Sahara dust episodes in Europe: literature review and research gaps, Environ Int., 15, 107-114, doi:10.1016/j.envint.2012.06.012, 2012.

Kaufman, Y. J., Tanré, D., Remer, L. A., Vermote, E. F., Chu, A., and Holben, B. N.: Operational remote sensing of tropospheric aerosol over land from EOS Moderate-resolution Imaging Spectroradiometer, J. Geophys. Res., 102, 17051-17065, 1997.

Kaufman, Y. J., Smirnov, A., Holben, B. N., and Dubovik, O.: Baseline maritime aerosol: methodology to derive the optical thickness and the scattering properties, Geophys. Res. Lett., 28, 32513254, 2001.

Klein, H., Nickovic, S., Haunold, W., Bundke, U., Nillius, B., Ebert, M., Weinbruch, S., Schuetz, L., Levin, Z., Barrie, L. A., and Bingemer, H.: Saharan dust and ice nuclei over Central Europe, Atmos. Chem. Phys., 10, 10211-10221, doi:10.5194/acp10-10211-2010, 2010.

Kubilay, N., Cokacar, T., and Oguz, T.: Optical properties of mineral dust outbreaks over the northeastern Mediterranean, J. Geophys. Res., 108, 4666, doi:10.1029/2003JD003798, 2003.

Lau, K. M., Kim, M. K., and Kim, K. M.: Asian summer monsoon anomalies induced by direct forcing: The role of the Tibetan plateau, Clim. Dynam., 26, 855-864, 2006.

Levy, R. C., Remer, L. A., Tanré, D., Kaufman, Y. J., Ichoku, C., Holben, B. N., Livingston, J. M., Russell, P. B., and Maring, H.: Evaluation of the Moderate-Resolution Imaging Spectroradiometer (MODIS) retrievals of dust aerosol over the ocean during PRIDE, J. Geophys. Res., 108, 8594, doi:10.1029/2002JD002460, 2003.

Levy, R. C., Remer, L. A., and Dubovik, O.: Global aerosol optical properties and application to Moderate Resolution Imaging Spectroradiometer aerosol retrieval over land, J. Geophys. Res., 112, D13210, doi:10.1029/2006JD007815, 2007.

Levy, R. C., Remer, L. A., Kleidman, R. G., Mattoo, S., Ichoku, C., Kahn, R., and Eck, T. F.: Global evaluation of the Collection
5 MODIS dark-target aerosol products over land, Atmos. Chem. Phys., 10, 10399-10420, doi:10.5194/acp-10-10399-2010, 2010.

Li, J., Carlson, B.E., and Lacis, A. A.: A study on the temporal and spatial variability of absorbing aerosols using Total Ozone Mapping Spectrometer and Ozone Monitoring Instrument Aerosol Index data, J. Geophys. Res., 114, D09213, doi:10.1029/2008JD011278, 2009.

Mallet, M., Tulet, P., Serça, D., Solmon, F., Dubovik, O., Pelon, J., Pont, V., and Thouron, O.: Impact of dust aerosols on the radiative budget, surface heat fluxes, heating rate profiles and convective activity over West Africa during March 2006, Atmos. Chem. Phys., 9, 7143-7160, doi:10.5194/acp-9-7143-2009, 2009.

Marrioti, A., Struglia, M. V., Zeng, N., and Lau, K.-M.: The Hydrological Cycle in the Mediterranean Region and Implications for the Water Budget of the Mediterranean Sea, J. Clim., 15, 1674 1690, 2002.

Meloni, D., di Sarra, A., Biavati, G., DeLuisi, J. J., Monteleone, F., Pace, G., Piacentino, S., and Sferlazzo, D. M.: Seasonal behavior of Saharan dust events at the Mediterranean island of Lampedusa in the period 1999-2005, Atmos. Environ., 41, 3041-3056, 2007.

Middleton, N. J. and Goudie, A. S.: Saharan dust: sources and trajectories, Trans Inst Br Georg, NS 26, 165-181, 2001.

Mona, L., Amodeo, A., Pandolfi, M., and Pappalardo, G.: Saharan dust intrusions in the Mediterranean area: Three years of Raman lidar measurements, J. Geophys. Res., 111, D16203, doi:10.1029/2005JD006569, 2006.

Moulin, C., Dulac, F., Lambert, C. E., Chazette, P., Jankowiak, I., Chatenet, B., and Lavenu, F.: Long-term daily monitoring of Saharan dust load over ocean using Meteosat ISCCP-B2 data 2. Accuracy of the method and validation using Sun photometer measurements, J. Geophys. Res., 102, 16959-16969, 1997.

Moulin, C., Lambert, C., Dayan, U., Masson, V., Ramonet, M., Bousquet, P., Legrand, M., Balkanski, Y., Guelle, W., Marticorena, B., Bergametti, G., and Dulac, F.: Satellite climatology of African dust transport in the Mediterranean atmosphere, J. Geophys. Res., 103, 13137-13144, 1998.

Nabat, P., Somot, S., Mallet, M., Chiapello, I., Morcrette, J. J., Solmon, F., Szopa, S., Dulac, F., Collins, W., Ghan, S., Horowitz, L. W., Lamarque, J. F., Lee, Y. H., Naik, V., Nagashima, T., Shindell, D., and Skeie, R.: A 4-D climatology (1979-2009) of the monthly tropospheric aerosol optical depth distribution over the Mediterranean region from a comparative evaluation and blending of remote sensing and model products, Atmos. Meas. Tech., 6, 1287-1314, doi:10.5194/amt-6-1287-2013, 2013.

Neff, J. C., Ballantyne, A. P., Farmer, G. L., Mahowald, N. M., Conroy, J. L., Landry, C. C., Overpeck, J. T., Painter, T. H., Lawrence, C. R., and Reynolds, R. L.: Increasing Eolian Dust Deposition in the Western United States Linked to Human Activity, Nat. Geosci., 1, 189-195, 2008.

Osborne, S. R., Baran, A. J., Johnson, B. T., Haywood, J. M., Hesse, E. and Newman, S.: Short-wave and long-wave radiative properties of Saharan dust aerosol, Q. J. Roy Meteorol. Soc., 137, 1149-1167, doi:10.1002/qj.771, 2011.

Pace, G., di Sarra, A., Meloni, D., Piacentino, S., and Chamard, P.: Aerosol optical properties at Lampedusa (Central Mediterranean). 1. Influence of transport and identification of different aerosol types, Atmos. Chem. Phys., 6, 697-713, doi:10.5194/acp-6-697-2006, 2006. 
Papadimas, C. D., Hatzianastassiou, N., Mihalopoulos, N., Querol, X., and Vardavas, I.: Spatial and temporal variability in aerosol properties over the Mediterranean basin based on 6year (2000-2006) MODIS data, J. Geophys. Res., 113, D11205, doi:10.1029/2007JD009189, 2008.

Papadimas, C. D., Hatzianastassiou, N., Mihalopoulos, N., Kanakidou, M., Katsoulis, B. D., and Vardavas, I.: Assessment of the MODIS Collections C005 and C004 aerosol optical depth products over the Mediterranean basin, Atmos. Chem. Phys., 9, 2987 2999, doi:10.5194/acp-9-2987-2009, 2009.

Papadimas, C. D., Hatzianastassiou, N., Matsoukas, C., Kanakidou, M., Mihalopoulos, N., and Vardavas, I.: The direct effect of aerosols on solar radiation over the broader Mediterranean basin, Atmos. Chem. Phys., 12, 7165-7185, doi:10.5194/acp-12-71652012, 2012.

Papayannis, A., Balis, D., Amiridis, V., Chourdakis, G., Tsaknakis, G., Zerefos, C., Castanho, A. D. A., Nickovic, S., Kazadzis, S., and Grabowski, J.: Measurements of Saharan dust aerosols over the Eastern Mediterranean using elastic backscatter-Raman lidar, spectrophotometric and satellite observations in the frame of the EARLINET project, Atmos. Chem. Phys., 5, 2065-2079, doi:10.5194/acp-5-2065-2005, 2005.

Papayannis, A., Amiridis, V., Mona, L., Tsaknakis, G., Balis, D., Bösenberg, J., Chaikovski, A., De Tomasi, F., Grigorov, I., Mattis, I., Mitev, V., Müller, D., Nickovic, S., Pérez, C., Pietruczuk, A., Pisani, G., Ravetta, F., Rizi, V., Sicard, M., Trickl, T., Wiegner, M., Gerding, M., Mamouri, R. E., D’Amico, G., and Pappalardo, G.: Systematic lidar observations of Saharan dust over Europe in the frame of EARLINET (2000-2002), J. Geophys. Res., 113, D10204, doi:10.1029/2007JD009028, 2008.

Papayannis, A., Mamouri, R. E., Amiridis, V., Kazadzis, S., Pérez, C., Tsaknakis, G., Kokkalis, P., and Baldasano, J. M.: Systematic lidar observations of Saharan dust layers over Athens, Greece in the frame of EARLINET project (2004-2006), Ann. Geophys., 27, 3611-3620, doi:10.5194/angeo-27-3611-2009, 2009.

Pérez, C., Nickovic, S., Baldasano, J. M., Sicard, M., Rocadenbosch, F., and Cachorro, V. E.: A long Saharan dust event over the western Mediterranean: Lidar, Sun photometer observations, and regional dust modeling, J. Geophys. Res., 111, D15214, doi:10.1029/2005JD006579, 2006.

Perez, L., Tobias, A., Querol, X., Kunzli, N., Pey, J., Alastuey, A., Viana, M., Valero, N., Gonzalez-Cabre, M., and Sunyer, J.: Coarse particles from Saharan dust and daily mortality, Epidemiology, 19, 800-807, 2008.

Pey, J., Querol, X., Alastuey, A., Forastiere, F., and Stafoggia, M.: African dust outbreaks over the Mediterranean Basin during 2001-2011: PM10 concentrations, phenomenology and trends, and its relation with synoptic and mesoscale meteorology, Atmos. Chem. Phys., 13, 1395-1410, doi:10.5194/acp-13-13952013, 2013.

Prospero, M. J., Ginoux, P., Torres, O., Nicholson, S. E., and Gill, T. E.: Enviromental characterization of global sources of atmospheric soil dust identified with the Nimbus 7 Total Ozone Mapping Spectrometer (TOMS) absorbing aerosol product, Rev. Geophys., 40, 1002, doi:10.1029/2000RG000095, 2002.

Pruppacher, H. R. and Klett, J. D.: Microphysics of clouds and precipitation, second revised and enlarged edition with an introduction to cloud chemistry and cloud electricity, 954 pp., Kluwer Academic Publishers, Dordrecht, the Netherlands, 1997.
Querol, X., Alastuey, A., Puicercus, J. A., Mantilla, E., Miro, J. V., Lopez-Soler, A., Plana, F., and Artiñano, B.: Seasonal evolution of suspended particles around a large coal-fired power station: particulate levels and sources, Atmos. Environ., 32, 1963-1978, 1998.

Querol, X., Pey, J., Pandolfi, M., Alastuey, A., Cusack, M., Pérez, N., Moreno, T., Viana, N., Mihalopoulos, N., Kallos, G. and Kleanthous, S.: African dust contributions to mean ambient $\mathrm{PM}_{10}$ mass-levels across the Mediterranean basin, Atmos. Environ., 43, 4266-4277, 2009.

Remer, L. A., Tanré, D., Kaufman, Y. J., Ichoku, C., Mattoo, S., Levy, R., Chu, D. A., Holben, B., Dubovik, O., Smirnov, A., Martins, J. V., Li, R.-R., and Ahman, Z.: Validation of MODIS aerosol retrieval over ocean, Geophys. Res. Lett., 29, 8008, doi:10.1029/2001GL013204, 2002.

Remer, L. A., Kaufman, Y. J., Tanré, D., Mattoo, S., Chu, D. A., Martins, J. V., Li, R. R., Ichoku, C., Levy, R. C., Kleidman, R. G., Eck, T. F., Vermote, E., and Holben, B. N.: The MODIS aerosol algorithm, products and validation, J. Atmos. Sci., 62, 947-973, 2005.

Remer, L. A. and Kaufman, Y. J.: Aerosol direct radiative effect at the top of the atmosphere over cloud free ocean derived from four years of MODIS data, Atmos. Chem. Phys., 6, 237-253, doi:10.5194/acp-6-237-2006, 2006.

Remer, L. A., Kleidman, R. G., Levy, R. C., Kaufman, Y. J., Tanré, D., Mattoo, S., Martins, J. V., Ichoku, C., Koren, I., Yu, H., and Holben, B. N.: Global aerosol climatology from the MODIS satellite sensors, J. Geophys. Res., 113, D14S07, doi:10.1029/2007JD009661, 2008.

Rodríguez, S., Querol, X., Alastuey, A., Kallos, G., and Kakaliagou O.: Saharan dust contributions to PM10 and TSP levels in Southern and Eastern Spain, Atmos. Environ., 35, 2433-2447, 2001.

Rosenfeld, D., Rudich, Y., and Lahav, R.: Desert dust suppressing precipitation: A possible desertification feedback loop, PNAS, 98, 5975-5980, 2001.

Sicard, M., Rocadenbosch, F., Reba, M. N. M., Comerón, A., Tomás, S., García-Vízcaino, D., Batet, O., Barrios, R., Kumar, D., and Baldasano, J. M.: Seasonal variability of aerosol optical properties observed by means of a Raman lidar at an EARLINET site over Northeastern Spain, Atmos. Chem. Phys., 11, 175-190, doi:10.5194/acp-11-175-2011, 2011.

Stammes, P. and Noordhoek, R.: OMI algorithm theoretical basis document, Clouds, Aerosols and Surface UV irradiance, Vol. III, http://eospso.gsfc.nasa.gov/eos_homepage/for_ scientists/atbd/docs/OMI/ATBD-OMI-03.pdf (last access: 13 November 2013), 2002.

Tafuro, A. M., Barnaba, F., De Tomassi, F., Perrone, M. R., and Gobbi, G. P.: Saharan dust particle properties over the Central Mediterranean, Atmos. Res., 81, 67-93, 2006.

Takemura, T., Nakajima, T., Dubovik, Holben, B. N., and Kinne, S.: Single-Scattering Albedo and Radiative Forcing of Various Aerosol Species with a Global Three-Dimensional Model, J. Clim., 15, 333-352, 2002.

Tanré, D., Kaufman, Y. J., Herman, M., and Mattoo, S.: Remote sensing of aerosol properties over oceans using the MODIS/EOS spectral radiances, J. Geophys. Res., 102, 16971-16988, 1997.

Tanré, D., Kaufman, Y. J., Holben, B. N., Chatenet, B., Karnieli, A., Lavenu, F., Blarel, L., Dubovik, O., Remer, L. A., and Smirnov, A.: Climatology of dust aerosol size distribution and optical 
properties derived from remotely sensed data in the spectral spectrum, J. Geophys. Res., 106, 18205-18217, 2001.

Tegen, I., Werner, M., Harrison, S. P., and Kohfeld, K. E.: Relative importance of climate and land use in determining present and future global soil dust emission, Geophys. Res. Lett., 31, L05105, doi:10.1029/2003GL019216, 2004.

Toledano, C., Cachorro, V. E., de Frutos, A. M. Sorribas, M., Prats, N., and de la Morena, B. A.: Inventory of African desert dust events over the southwestern Iberian Peninsula in 2000-2005 with an AERONET Cimel Sun Photometer, J. Geophys. Res., 112, D21201, doi:10.1029/2006JD008307, 2007.

Toledano, C., Wiegner, M., Garhammer, M., Seefeldner, M., Gasteiger, J., Müller, D., and Koepke, P.: Spectral aerosol optical depth characterization of desert dust during SAMUM2006, Tellus B, 61, 216-228, 2009.

Torres, O., Bhartia, P. K., Herman, J. R., Ahmad, Z., and Gleason, J.: Derivation of aerosol properties from a satellite measurements of backscattered ultraviolet radiation: Theoretical basis, J. Geophys. Res., 103, 17099-17110, 1998.

Torres, O., Bhartia, P. K., Herman, J. R., Sinyuk A., and Holben, B.: A long term record of aerosol optical thickness from TOMS observations and comparison to AERONET measurements, J. Atmos. Sci., 59, 398-413, 2002.

Torres, O., Tanskanen, A., Veihelman, B., Ahn, C., Braak, R., Bhartia, P. K., Veefkind, P., and Levelt, P.: Aerosols and Surface UV Products from OMI Observations: An Overview, J. Geophys. Res., 112, D24S47, doi:10.1029/2007JD008809, 2007.
Washington, R., Todd, M., Middleton, M. J., and Goudie, A. S.: Dust-storm source areas determined by the Total Ozone Monitoring Spectrometer and surface observations, Ann. Assoc. Am. Geogr., 93, 297-313, 2003.

Xia, X. and Zong, X.: Shortwave versus longwave direct radiative forcing by Taklimakan dust aerosols, Geophys. Res. Lett., 36, L07803, doi:10.1029/2009GL037237, 2009.

Yang, E.-S., Gupta, P., and Christopher, S. A.: Net radiative effect of dust aerosols from satellite measurements over Sahara, Geophys. Res. Lett., 36, L18812, doi:10.1029/2009GL039801, 2009.

Yoon, J., von Hoyningen-Huene, W., Vountas, M., and Burrows, J. P.: Analysis of linear long-term trend of aerosol optical thickness derived from SeaWiFS using BAER over Europe and South China, Atmos. Chem. Phys., 11, 12149-12167, doi:10.5194/acp11-12149-2011, 2011.

Zhang, J. and Reid, J. S.: A decadal regional and global trend analysis of the aerosol optical depth using a data-assimilation grade over-water MODIS and Level 2 MISR aerosol products, Atmos. Chem. Phys., 10, 10949-10963, doi:10.5194/acp-1010949-2010, 2010.

Zhang, J. L., Reid, J. S., and Holben, B. N.: An analysis of potential cloud artifacts in MODIS over ocean aerosol optical thickness products, Geophys. Res. Lett., 32, L15803, doi:10.1029/2005GL023254, 2005. 